\title{
MOSS DIVERSITY PATTERNS ON THE TERRITORY OF THE FORMER USSR
}

\section{ОСОБЕННОСТИ РАЗНООБРАЗИЯ ФЛОР МХОВ НА ТЕРРИТОРИИ БЫВШЕГО СССР}

\author{
MICHAEL S. IGNATOV 1 \\ МИХАИЛ С. ИГНАТОВ 1
}

\begin{abstract}
The moss diversity on the territory of the former USSR is analyzed on the basis of recently published check-list. Oceanic sides of Eurasia and mountain areas appears to be much more rich in species number, than continental lowlands, especially in comparison with quite a different situation in vascular plants. Specifics of regions of the former USSR are demonstrated and the total species diversity is expanded on 9 main geographic elements, and their significance is evaluated.
\end{abstract}

Резюме

На основе анализа списка видов мхов территория бывшего Советского Союза (Arctoa, vol. 1) рассматривается видовое богатство моховых флор Северной Евразни. При этом приокеанические и горные районы оказываются существенно богаче видами, чем континентальные равнины, что сильно отличает характер видового разнообразия мхов от такового сосудистых растений. Показана специфика флор мхов отдельных регионов бывшего СССР, а также предложена схема, представляющая общее разнообразие как результат суперпозиции 9 основных типов ареалов, с оценкой вклада каждопо из них.

\section{INTRODUCTION}

In 1975 L. I. Malyshev has published an interesting paper on the spatial diversity of vascular plants and their richness in regional floras. There was provided a map where isolines indicate the number of species for an area of $100000 \mathrm{~km}^{2}$. This size of area is especially useful since many lists or floras deal with approximately such an area.

As one can assume from that map (partly reproduced on Fig. 1) isolines within Northern Eurasia are mostly parallel to the equator. Some concenters of floristically enriched regions are in mountains of South Ural and especially in Central European Mediterranean regions.

Analyzing data from the territory of the former USSR, and, to a less extend, from other parts of Holarctic, I have found that the situation with the spatial diversity of mosses is considerably different: oceanic and mountain areas $(\mathrm{O}, \mathrm{M})$ being more rich in species number than inland lowlands (IL), have the rate between them ("O \& $\mathrm{M}$ : IL") sufficiently higher in mosses than in vascular plants. The main reason for this is, probably due to the relatively high diversity of vascular plants in steppes and deserts where bryophytes are poorly represented both in number of species and in number of individuals. So isolines on the map of moss diversity in Northern Eurasia typically are not parallel to the equator, but surround the regions with more wet and mild climate (Fig. 2). To argument this observation and the map is the task of the present paper.

\section{RELATIONSHIP BETWEEN AREA AND SPECIES NUMBER}

Some methodological questions should be answered first: 1) what is the appropriate area for such a comparison; 2) how is the number of species in a moss flora affected by the area investigated?

1 - Russia 127276 Moscow, Botanicheskaya 4, Main Botanical Garden, Russian Acad. Sci. - Poccug 127276 Москва, Ботаническая 4, Главный ботанический сад РАН. 
The answer to the first question depends to a great extend on current practice of floristic investigation. Floras usually are elaborating for two types of territories. The first are of 0.1 to $100 \mathrm{~km}^{2}$ (National Parks, different kinds of Reserves, territories of botanical gardens, special interesting places, surroundings of cities) - such areas, in many cases, can be explored in several days to weeks, or by a number of periodical visits. The second area size is from 10000 to $1000000 \mathrm{~km}^{2}$ - it is the average area of many European countries, many states, provinces, territories in big countries like former USSR, USA, Canada, China, etc. The results of investigations of such areas are usually present in handbooks, complete "Floras" or, in recent time, also in numerous check-lists. The problem with the usage of data of smaller areas $\left(0.1\right.$ to $\left.100 \mathrm{~km}^{2}\right)$ is that most of them are territories more or less outstanding with respect to bryophytes. For example, in the lowland European part of Russia, one can find in the valley of a more or less big river 2-3 times more species than in more flat area without rivers / big creeks. And bryodiversity here depends on the diversity of relief, height of slopes, kind of rocks, level of human impact (occurring too strongly in many provinces) and many other factors. In mountain area with very diverse natural conditions, the number of species, as I can assume, strongly depends on the time, a bryologist can devote to do the field work. I know only few localities of high mountains in the former USSR territory, which can be said to be explored enough to provide the basis for comparative studies. By these reason, I think that comparison of local floras (so common in floristics of vascular plants), is premature for bryophytes.

What about bryofloras of areas of $10000-1000000 \mathrm{~km}^{2}$, it seems that they are more evenly investigated, comparatively with the smaller area variant. So, I believe that their comparison can elucidate the main characteristics of the relationship between number of species/area studied, even when comparison is made for different regions of Holarctic.

As it can be seen from Table 1 (graph- ically displayed on Fig. 3), the relationship between the area investigated and the number of species is though positive, but comparatively with vascular plants the line of regression is nearly horizontal ${ }^{1}$ (Fig. 3). So it is clear that differences in quality of exploration and the taxonomical concepts ("splitter / lamper") are maybe more important, at least today, than the differences caused by the area size under exploration in the interval of $10000-1000000 \mathrm{~km}^{2}$. So, in evaluating of the theoretical number of species of $100000 \mathrm{~km}^{2}$ for the map of moss diversity (Fig. 2), I took into consideration all these factors, especially the level of exploration of an area. The resulting picture of moss diversity on the territory of the former USSR in Fig. 2 is based, therefore, on data taken from Tables $1 \& 2$, with my own indexing. And though my subjectivity remains unrecoverable here, I believe that such an evaluation is, at least, no less inaccurate than mathematical calculation based on presently available data. For the outline of some regions for Fig. 2, the maps of distribution of some moss species, as well as general maps of physiography and vegetation were also useful (Atlas SSSR, 1984).

The overall picture of moss diversity pattern was investigated in the course of preparing of the "Check-list of mosses of the former USSR" (Arctoa,1). Some practical consequences derived from Fig. 2 are:

1) the division of "Flora Europaea" (Tutin \& al. 1964 1980) repeated by Duell $(1984,1985)$ for the European part of the USSR, uses regions with latitudes much smaller than longitudes (especially Northern and Central regions of the European part of former USSR). Maybe it is naturally for vascular plants with their well-established

1 - This difference can be illustrated with some examples: in Moscow Province there are known ca. $5 \%$ of species of vascular plants of the entire USSR (Woroschilov \& al., 1966; Czerepanov, 1981), while for mosses this number is ca. $25 \%$ (Ignatov \& Ignatova, 1990; Ignatov \& Afonina, 1992); or Swedish vascular flora is ca. $20 \%$ of that of Europe (Hulten, 1971; Lid, 1963; Tutin, 1964-1980), while for mosses - ca. $70 \%$ (Hallingbaeck \& Soederstroem, 1987; Corley \& Crundwell, 1991). Selected small area can contain up to half of the moss flora of a very much larger territory. For example, in Kunzevo in Moscow, on a 100 ha $(0.00002 \%$ of territory of Moscow Province) there are represented 130 species of mosses, or half of the number for the Province; or in South Wales (Hill, 1988) there is found about half of the moss flora of Europe on about $0.1 \%$ of territory of the latter, etc. 


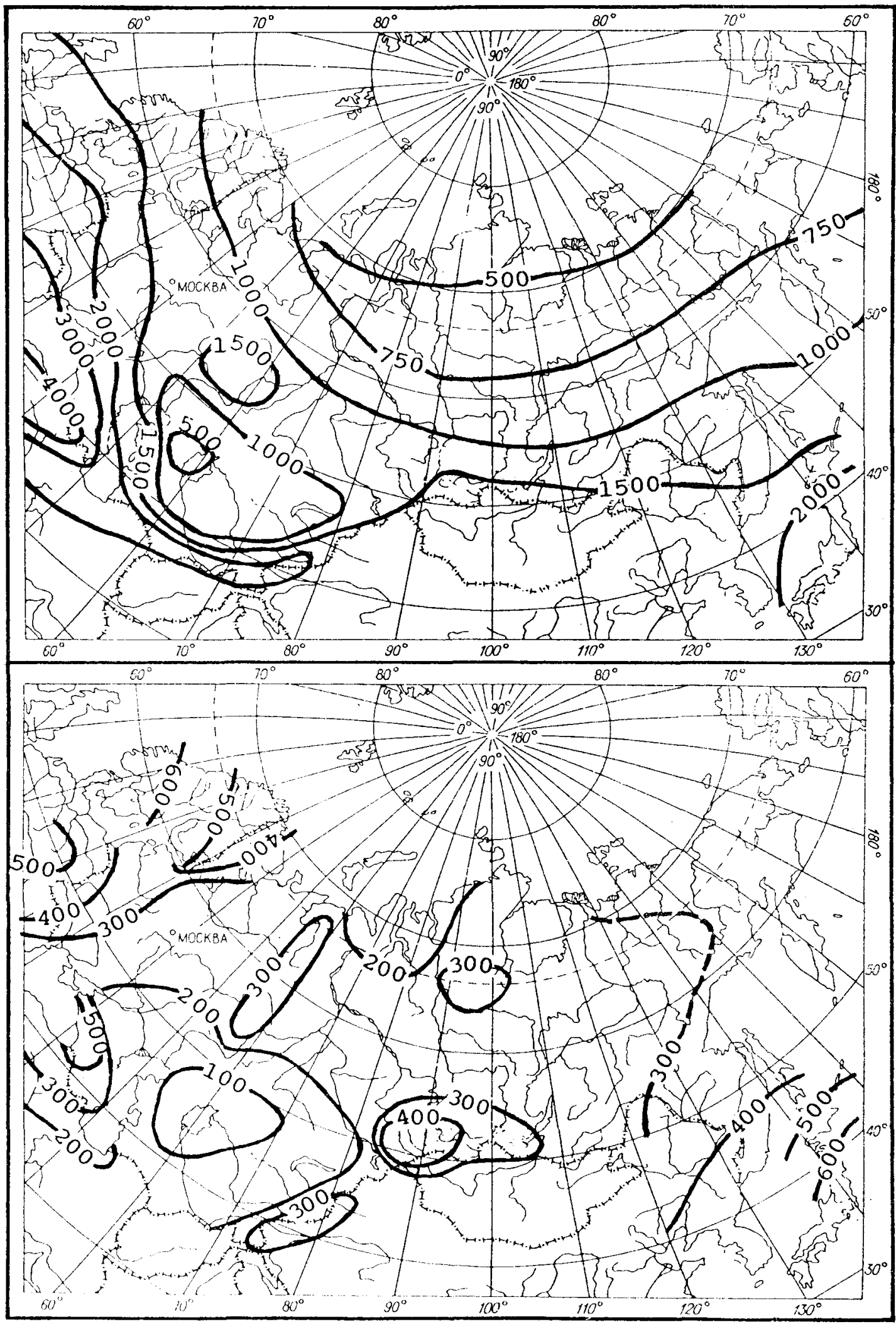

Figs. 1 - 2. Number of species in floras of vascular plants (1) and of mosses (2) on the territory of the former USSR and neighboring areas (approximation to area of $100000 \mathrm{~km}^{2}$ ). Fig. 1 - after Malyshev (1975). 
Table 1. Number of moss species in regional floras.

\begin{tabular}{|c|c|c|c|}
\hline Territory & $\begin{array}{l}\text { Number of } \\
\text { species }\end{array}$ & Area, $\mathbf{k m}^{2}$ & Reference \\
\hline Arabian Peninsula & 51 & 2985 & Frey, 1986 \\
\hline Trans-Jordan Area & 110 & ca. 90 & El-Oqlah \& al., 1988 \\
\hline Moldova (within ex-USSR) & 143 & 34 & Simonov, 1978 \\
\hline Iraq & 145 & 435 & Agnew \& Wondracek, 1975 \\
\hline Darvaz Mt Range, Middle Asia & 156 & ca. 10 & Mamatkulov, 1975 \\
\hline Afganistan & 182 & 647 & Frey, 1986 \\
\hline Pridneprovskaya Upland, Ukraine & 188 & ca. 40 & Virchenko, 1989 \\
\hline Lebanon + Syria + Jordan & 199 & 293 & Frey, 1986 \\
\hline \multicolumn{4}{|l|}{ Don River Basin in Middle Course, } \\
\hline Russia & 203 & 60 & Khmelev \& Popova, 1988 \\
\hline Saskatchevan, Canada & 208 & 570 & Ireland \& al., 1987 \\
\hline Tomsk Province, Russia & 220 & 314 & Muldiyarov, 1990 \\
\hline Arctic Archipelago, Canada & 230 & ca. 1000 & Ireland \& al., 1987 \\
\hline Lithueva (Litva) & 231 & 65 & Yukonene, 1991 \\
\hline Israel & 232 & 14 & Herrnstadt \& al., 1991 \\
\hline Gorkij Province, Russia & 238 & 75 & Vorobjov, 1983 \\
\hline Sakhalin Island (southern part) & 238 & са. 30 & Ardeeva, 1969 \\
\hline South-East Armenia & 243 & 8 & Manakyan, 1989b \\
\hline Iran & 259 & 1648 & Frey, 1986 \\
\hline Krym (Crimea) Peninsula & 268 & 26 & Partyka, 1989 \\
\hline Manitoba, Canada & 269 & 650 & Ireland \& al., 1987 \\
\hline Moscow Province, Russia & 269 & 47 & Ignatov \& Ignatova, 1990 \\
\hline Bashkiria, South Ural Mis. & 302 & 143 & Ignatova \& Ignatov, 1992 \\
\hline Belorussia & 315 & 208 & Rykovskiy, 1980 \\
\hline Pamiro-Alaj Mts., Middle Asia & 320 & ca.100 & Mamatkulov, 1989 \\
\hline \multicolumn{4}{|l|}{ North-West Territories, Canada } \\
\hline (continental part) & 321 & ca. 2400 & Ireland \& al., 1987 \\
\hline Yakutian tundras, Northern Siberia & ia 322 & 394 & Stepanova, 1986 \\
\hline Mongolia & 329 & 1565 & Abramov \& Abramova, 1983 \\
\hline Eastern Sayan Mts., South Siberia & 332 & ca. 100 & Bardunov, 1974 \\
\hline Western Sayan Mts., South Siberia & 339 & ca. 100 & Bardunov, 1974 \\
\hline Intermountain West, USA & 342 & ca. 500 & Spence, 1988 \\
\hline Leningrad Prov., Russia & 343 & 86 & Vjyunova, 1980 \\
\hline Armenia & 355 & 30 & Manakyan, 1989a \\
\hline Estonia & 361 & 45 & Kannukene, 1986 \\
\hline Chukotka Peninsula & 361 & ca. 90 & Afonina, 1989 \\
\hline Azerbaidjan & 364 & 87 & Lyubarskaya, 1986 \\
\hline Latvija & 368 & 65 & Abolina, 1968 \\
\hline Yukon Territories, Canada & 364 & 536 & Ireland \& al., 1987 \\
\hline Netherlands (without Sphagnum) & 389 & 41 & Touw \& Rubers, 1989 \\
\hline Komi Republic, Russia & 411 & 416 & Zheleznova, 1991 \\
\hline Iceland & 414 & 103 & Johannsson, 1983 \\
\hline
\end{tabular}


Table 1 (concluded).

\begin{tabular}{|c|c|c|c|}
\hline Territory & $\begin{array}{l}\text { Number of } \\
\text { species }\end{array}$ & Area, $\mathrm{km}^{2}$ & Reference \\
\hline $\begin{array}{c}\text { South Primorskiy Prov., } \\
\text { Russian Far East }\end{array}$ & 420 & $\mathrm{ca} .50$ & $\begin{array}{l}\text { Bardunov \& } \\
\text { Czerdantseva, } 1982\end{array}$ \\
\hline Hungary & 422 & 93 & Boros, 1968 \\
\hline Alberta, Canada & 422 & 661 & Ireland \& al., 1987 \\
\hline Greece & 424 & 132 & Preston, 1984 \\
\hline Murmansk Prov., Russia & 437 & 145 & $\begin{array}{l}\text { Schljakov \& } \\
\quad \text { Konstantinova, } 1982\end{array}$ \\
\hline Altai Mts. within ex-USSR & 452 & ca.100 & personal data \\
\hline Denmark & 461 & 43 & Dirske \& al., 1988 \\
\hline Ontario, Canada & 467 & 1068 & Ireland \& al., 1987 \\
\hline Turkey + Cyprus & 470 & 781 & Frey, 1986 \\
\hline North-East China & 472 & ca. 800 & Gao \& Chang, 1983 \\
\hline Makaronesia & 485 & $\mathrm{ca} .11$ & Eggers, 1982 \\
\hline Georgia & 496 & 70 & Chikovani, 1986 \\
\hline Rheinland-Pfalz & 499 & ca. 15 & Duell \& al., 1983 \\
\hline Bulgaria & 502 & 111 & Petrov, 1975 \\
\hline Quebeck, Canada & 506 & 1540 & Ireland \& al., 1987 \\
\hline Northern Wales & 546 & 13 & Hill, 1988 \\
\hline Finland & 591 & 337 & Koponen \& al., 1977 \\
\hline British Columbia, Canada & 655 & 949 & Ireland \& al., 1987 \\
\hline Spain & 668 & 505 & Casas, 1981 \\
\hline Poland & 677 & 313 & Ochyra \& al, 1992 \\
\hline Britain \& Ireland & 692 & 316 & Smith, 1978 \\
\hline Eastern North America & 752 & ca. 7000 & Crum \& Anderson, 1981 \\
\hline Sweden & 753 & 449 & $\begin{array}{l}\text { Hallingbaeck \& } \\
\quad \text { Soederstroem, } 1987\end{array}$ \\
\hline Japan & $\mathrm{ca} .900$ & 372 & Noguchi, 1987 \\
\hline Canada & 965 & 9976 & Ireland \& al., 1987 \\
\hline Former USSR & 1157 & 22400 & Ignatov \& Afonina, 1992 \\
\hline Europe & 1154 & 11600 & Corely \& Crundwell, 1991 \\
\hline USA \& Canada & 1320 & 17815 & Anderson \& al., 1990 \\
\hline China & 2004 & 9597 & Redfearn \& Wu, 1986 \\
\hline World & 7000 & 149000 & Touw, 1974 \\
\hline World & 9000 & 149000 & Crosby, 1980 \\
\hline
\end{tabular}

latitudinal boundaries. But in mosses, longitudinal limits are much more important, so it is necessary to divide the territory along the oceanic-continental gradient. However "Flora Europaea" borders are mostly accepted, with a few weak shifts. The principal one is that St-Petersburg (Leningrad) Province was removed from the Central Region and included in the oceanic alliance of provinces (NW, B, BLR, W, K).
2) more diverse and peculiar with respect to bryophytes South Siberia is separated from the flattened northward territories. At the same time Altai Mts. and Sayan Mts., which usually were separated by traditional division into Western and Eastern Siberia, are combined here: altaian additional diversity in vascular plants (because of many xerophytic groups) is practically absent in regard to mosses. 
NUMBER OF SPECIES AND PECULIARITIES OF REGIONS OF THE EX-USSR

According to the recently published check-list of mosses of the former USSR (Ignatov \& Afonina, 1992) on its territory there are known 1157 species and 74 infraspecific taxa, including, however, 43 species and 1 variety considered as dubious. The territory was divided into 6 main regions - Arctic, European part, Caucasus, Siberia, Far East and Middle Asia, in general following the main division using for vascular plants in the Flora of the USSR (Komarov, 1934-66). In most regions (except Caucasus and Middle Asia) there are subdivisions, and the total number of recognized geographical entities is 21 . The number of taxa, known for these divisions is represented in Table 2.

Though the correlation in number of species in common between of the regions of Holarctic is at about $85 \%$ (cf. Schofield $1988 \mathrm{~b}$; Ignatov 1992), the number of species in common among all the six principal divisions of the former USSR is unexpectedly low - only $17 \%$, or 200 species (listed below). And only ca. 3\% of species (36) are known in all the 21 subdivisions of the former USSR (marked with * in this list): *Abietinella abietina, Amblystegium serpens, A. varium, Amphidium lapponicum, A. mougeotii, Andreaea rupestris, Anomobryum julaceum, Anomodon viticulosus, Aulacomnium palustre, Barbula convoluta, B. ungu- iculata, Bartramia ithyphylla, B. pomiformis, Brachythecium albicans, B. campestre, " $B$. mildeanum, $B$. plumosum, $B$. populeum, $B$. reflexum, $B$. rivulare, ${ }^{*} B$. salebrosum, $B$. starkei, B. velutinum, ${ }^{*}$ Bryoerythrophyllum recurvirostrum, Bryum algovicum, ${ }^{*} B$. argenteum, ${ }^{*} B$. caespiticium, B. capillare, B. creberrimum, $B$. funckii, $B$. intermedium, $B$. pallens, B. pallescens, ${ }^{*} B$. pseudotriquetrum, B. schleicheri, B. weigelii, Calliergon cordifolium, C. giganteum, C. stramineum, Calliergonella cuspidata, Campylium polygamum, ${ }^{*}$ C. stellatum, *Ceratodon purpureus, Cirriphyllum cirrosum, *Climacium dendroides, Coscinodon cribrosus, *Cratoneuron filicinum, Ctenidium molluscum, Cynodontium tenellum, Desmatodon latifolius, Dicranella subulata, Dicranella varia, Dicranoweisia crispula, Dicranum bonjeanii, D. brevifolium, $D$. congestum, $D$. elongatum, $D$. muehlenbec$k i i, D$. polysetum, ${ }^{*} D$. scoparium, $D$. spadiceum, Didymodon fallax, $D$. rigidulus, $D$. vinealis, 'Distichium capillaceum, D. inclinatum, Ditrichum flexicaule, ${ }^{*}$ Drepanocladus aduncus, ${ }^{*} D$. sendtneri, Encalypta ciliata, $E$. rhaptocarpa, E. streptocarpa, E. vulgaris, Entodon concinnus, "Eurhynchium pulchellum, Fissidens adianthoides, ${ }^{*} F$. bryoides, $F$. osmundoides, Fontinalis antipyretica, $F$. hypnoides, *Funaria hygrometrica, Grimmia alpestris, G. donniana, G. elatior, G. elongata, G. montana, G. ovalis, Gymnostomum aeruginosum, Hedwigia ciliata, Helodium blandowii, Hygrohypnum duriusculum,

Fig. 3. Relationship between number of moss species in some regions and area of these regions (see also Tab. 1).

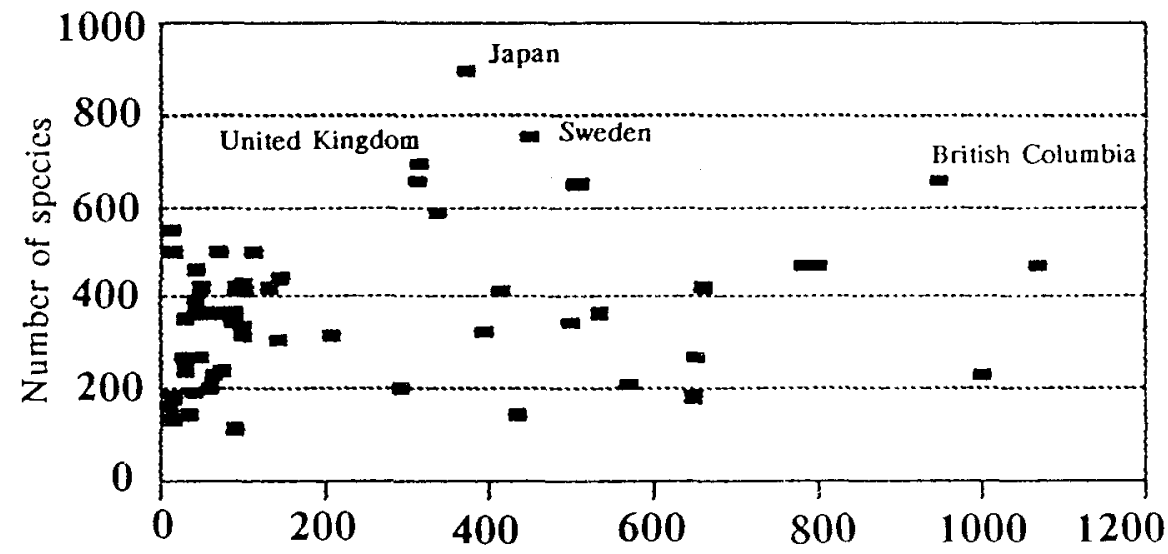

Area $\times 1000 \mathrm{~km}^{2}$ 
Table 2. Number of moss species in the regions of the former USSR (the names of regions are in some cases shortened; for their precise definitions see Arctoa, vol 1).

\begin{tabular}{|c|c|c|}
\hline Regions of the former USSR & $\begin{array}{l}\text { Number of species } \\
\text { (+infraspecific taxa) }\end{array}$ & $\begin{array}{c}\text { Area, } \\
\mathrm{km}^{2} \times 10^{3}\end{array}$ \\
\hline $\begin{array}{lr}\text { Arctic } & A R C \\
\text { European Arctic } & E U R O \\
\text { West-Siberian Arctic } & W S \\
\text { East-Siberian Arctic } & E S \\
\text { Beringian Arctic } & B E \\
\text { European part } & E U R \\
\text { North-West } & N W \\
\text { North-East } & N E \\
\text { North Ural } & N-U R \\
\text { Baltic Countries } & B \\
\text { Belorussia } & B L R \\
\text { Central Russia } & C \\
\text { West (Ukraine \& Moldova) } & W \\
\text { Krym (Crimea) } & K \\
\text { East (South-East) } & E \\
\text { South Ural } & S-U R \\
\text { Caucasus } & C A U C \\
\text { Siberia } & S I B \\
\text { West Siberia } & W \\
\text { East Siberia } & E \\
\text { South Siberia } & S \\
\text { Far East } & F A R E A S T \\
\text { northern part } & N \\
\text { southern part } & S \\
\text { Middle Asia } & M I D A S\end{array}$ & $\begin{array}{l}506(+34) \\
361(+22) \\
237(+8) \\
371(+27) \\
390(+24) \\
782(+49) \\
554(+24) \\
374(+25) \\
311(+6) \\
453(+23) \\
334(+12) \\
351(+18) \\
572(+28) \\
253(+13) \\
243(+13) \\
363(+12) \\
627(+42) \\
625(+40) \\
286(+11) \\
399(+19) \\
560(+35) \\
635(+29) \\
321(+17) \\
555(+19) \\
489(+40)\end{array}$ & $\begin{array}{c}1250 \\
250 \\
200 \\
500 \\
300 \\
4310 \\
370 \\
700 \\
150 \\
190 \\
210 \\
1300 \\
610 \\
30 \\
500 \\
250 \\
350 \\
9300 \\
1900 \\
4900 \\
2500 \\
3100 \\
1900 \\
1200 \\
3980\end{array}$ \\
\hline total & $1157(+74)$ & 22400 \\
\hline
\end{tabular}

*H. luridum, H. ochraceum, *Hylocomium splendens, Hymenostylium recurvirostre, *Hypnum cupressiforme, $H$. lindbergii, $H$. revolutum, $H$. vaucheri, Isopterygiopsis pulchella, Leptobryum pyriforme, Leptodictyum humile, L. riparium, Lescuraea saxicola, Leskea polycarpa, Leskeella nervosa, Leucodon sciuroides, Limprichtia cossoni, $L$. revolvens, Meesia uliginosa, Mnium ambiguum, $M$. marginatum, $M$. spinosum, $M$. spinulosum, $M$. stellare, $M$. thomsonii, Molendoa sendtneriana, Myurella julacea, $M$. tenerrima, Oncophorus virens, $O$ wahlenbergii, Orthotrichum anomalum, $O$ obtusifolium, O. speciosum, Oxystegus tenuirostris, Paludella squarrosa, Palustriella commutata, $P$. decipiens, Paraleucobryum enerve, $P$. longifolium, *Philonotis fontana, Plagiobryum zieri, Plagiomnium cuspidatum, *P. ellipticum, ${ }^{*} P$. medium, Plagiopus oederiana, Plagiothecium denticulatum, $P$. laetum, Platydictya jungermannioides, $P$. subtilis, Platygyrium repens, *Pleurozium schreberi, *Pogonatum urnigerum, *Pohlia cruda, $P$. elongata, P. filum, $P$. longicollis, *P. nutans, *P. wahlenbergii, Polytrichastrum alpinum, Polytrichum commune, $* P$. $O$. juniperinum, ${ }^{*} P$. piliferum, $P$. strictum, 
Pseudobryum cinclidioides, Pseudoleskea incurvata, $P$. radicosa, $P$ seudoleskeella catenulata, $P$. tectorum, Pterigynandrum filiforme, Ptilium crista-castrensis, Pylaisiella polyantha, Racomitrium canescens, Rhizomnium pseudopunctatum, R. - punctatum, Rhodobryum roseum, *Rhytidiadelphus triquetrus, Rhytidium rugosum, Saelania glaucescens, *Sanionia uncinata, Sarmentypnum sarmentosum, Schistidium agassizii, *S. apocarpum, S. rivulare, S. strictum, Sphagnum capillifolium, $S$. centrale, $S$. contortum, S. flexuosum, S. fuscum, S. girgensohnii, *S. magellanicum, $S$. platyphyllum, $S$. russowii, $S$. squarrosum, $S$. subsecundum, $S$. teres, S. warnstorfii, Tetraphis pellucida, Thuidium philibertii, Timmia megapolitana, $T$. norvegica, Tortella fragilis, $T$. inclinata, $T$. tortuosa, Tortula mucronifolia, $T$. norvegica, * $T$. ruralis, Trichostomum crispulum, Ulota curvifolia, Warnstorfia exannulata, W. fluitans. It is interesting that only 9 genera out of 99 in the above list have more than three species: Sphagnum (13), Bryum (12), Brachythecium (10), Dicranum (8), Mnium (6), Grimmia (6), Pohlia (6), Schistidium (4), Hypnum (4).

On the peculiarity of bryophyte flora of accepted regions it is possible to note the following. The most particular area in the former USSR is the region of Far East, where are known 130 species which are absent in all the other parts of the USSR, and among them 119 are known only from its southern part. There is a considerable number of genera, occurring in the former USSR only here: Actinothuidium, Atractylocarpus, Bartramiopsis, Boulaya, Brachymenium, Brotherella, Bryachenea, Dolichomitriopsis, Dozya, Drummondia, Fauriella, Gly. phomitrium, Homaliadelphus, Hondaella, $\mathrm{Hy}$ locomiopsis, Hypopterygium, Macromitrium, Mamillariella, Miyabea, Oedipodium, Okamuraea, Pleuroziopsis, Pseudoleskeopsis, Rauiella, Rigodiadelphus, Schwetschkeopsis, Vesicularia. There are also a lot of interesting and peculiar species here - Anomodon giraldii, $A$. solovjovii, Aulacomnium heterostichum, Camptothecium auriculatum, Claopodium crispifolium, Climacium japonicum, 3 species of Cyrto-hypnum (C. pyg- maeum, C. sparsifolium, C. vestitissimum), 8 species of Entodon ( $E$. diversinervis, $E$. giraldii, E. luridus, E. rubicundus, E. rufescens, E. scabridens, E. sinense, E. sullivantii var. versicolor), Fissidens adelphinus, $F$. nobilis, 3 species of Forsstroemia ( $F$. japonica, F. stricta, F. trichomitria), Gollania ruginosa, Haplohymenium flagelliforme, Homomallium connexum, $H$. plagiangium, Homalothecium laevisetum, Isothecium hakkodense, Leucodon pendulus, Lindbergia japonica, Neckera yesoana, Oligotrichum aligerum, $O$. parallelum, Plagiothecium obtusissimum, 4 species of Pogonatum ( $P$. contortum, $P$. inflexum, $P$. japonicum, $P$. spinulosum), 4 species of Pylaisiella ( $P$. brotheri, $P$. intricata, $P$. obtusa, $P$. subcircinata), Rhizomnium nudum, $R$. striatulum, 3 species of Taxiphyllum ( $T$. alternans, $T$. aomoriense, $T$. taxirameum), Tetraphis geniculata, 4 species of Thamnobryum ( $T$. coreense, $T$. plicatulum, $T$. subseriatum, $T$. vorobjovii), 5 species of Thuidium ( $T$. cymbifolium, $T$. glaucinum, $T$. kanedae, T. molkenboeri, $T$. submicropteris), Trachycystis flagellaris, T. microphyllus, etc. this is just an incomplete list, including the most phytogeographically interesting taxa and groups. Again it is worthwhile to note that Russian Far East is still rather incompletely explored.

The 2 species confined only to Northern part of Far East are of rather dubious taxonomic status (Pseudoleskeella korjakorum and Timmiella corniculata, the latter probably is conspecific with the widespread in Western North America $T$. crassinervia). Only 9 species of those confining to the Russian Far East, are known both in its Northern and Southern parts. And most of them occur also in Western North America, representing well-known pattern of North Pacific Arc (Bartramiopsis lescurii, Bryhnia hultenii, Oligotrichum parallelum, Pleuroziopsis ruthenica, Pogonatum contortum, Polytrichum sphaerothecium, Rhizomnium nudum).

The number of species limited in the former USSR only in Far East and Beringian Arctic, is unexpectedly low - only 2 species, (Bryoxiphium norvegicum and Herzogiella ascendens). Moreover both are known in the Northern Europe and in the North America. 
The number of species in common between Far East and South Siberia which are, however, unknown from any other part of USSR, is much greater - 21: Anacamptodon latidens, Anomodon minor ssp. integerrimus, A. thraustus, Brachythecium buchananii, Brothera leana, Bryohaplocladium angustifolium, Buxbaumia minakatae, Eurohypnum leptothallum, Grimmia pilifera, Haplohymenium longinerve, Helodium paludosum, Herpetineuron toccoae, Hyophila involuta, Leptodontium styriacum, Neckera borealis, Plagiomnium maximoviczii, Plagiomnium vesicatum, Ptychomitrium sinense, Pylaisiadelpha tenuirostris, Rhizomnium parvulum, Zygodon conoideus. And it is interesting that no one of them is distributed in the northern part of the Far East. Obviously, most of these species could be understood as the more resistant portion of the East Asian route, concentrating mostly in Far East. Many of them represent classical disjunction between East Asia and Eastern North America.

There are 12 species confined to the Siberia + Arctic + Far East: Aulacomnium acuminatum, Cinclidium latifolium, Hypnum subimponens, Lyellia aspera, Oligotrichum falcatum, Orthotrichum sordidum, Podperaea krylovii, Racomitrium panschii, Scouleria aquatica, Sphagnum orientale, S. perfoliatum, Trichostomum arcticum, many of them occur also in America, being connected via the North Pacific Arc.

There are 27 species known only from Siberia. This number, however, includes 9 species, described from Eastern Siberia by Lindberg \& Arnell (1890), and known mostly by their type collections, so their status needs confirmation (Bryum calcicola, B. jeniseense, $B$. planiusculum, $B$. sibiricum, Cinclidium minutifolium, Myurella acuminata, Pohlia alba, $P$. brevinervis, $P$. viridis). The only endemic species of Eastern Siberia, whose taxonomic rank seems unquestionable, is Myuroclada rotundifolia (= Myrinia rotundifolia). It is a very interesting, distinct moss known from a few localities in the lower course of Lena River, near the border of Arctic region.

There is no species known only from Western Siberia. This lowland territory of steppe vegetation to the south and discontinuous Sphagnum bogs to the north is very poor in bryophytes. So the absence of specificity here is quite natural.

Fifteen species occur in the former USSR only in South Siberia: ${ }^{*}$ Bryoerythrophyllum inaequalifolium, *Aongstroemia orientalis, *A. julacea, *Barbula amplexifolia, *Brachythecium wichurae, Bryum altaicum, Didymodon perobtusus, Entodon transbaicalensis, *Forsstroemia noguchii, * Gollania turgens, Grimmia cavifolia, Jaffueliobryum latifolium, Orthodontopsis bardunovii, Schistidium liliputanum, *Struckia argentata ssp. zerovii. Nearly all of these species are well-reputated taxa. Many are strongly disjunctive with the remote southern regions (marked by asterisk *), or (Barbula, Gollania) a $1 \mathrm{~s}$ o with Arctic.

There are as many as 61 species, restricted in their distribution in the former USSR only to Middle Asia. This number, however, is strongly affected by many dubious species, which badly need a revision. Especially it is concerning to 23 species of Bryum, mostly described by Philibert. Among other species there are Dicranella howei, 3 species of Entostodon ( $E$. angustifolius, $E$. attenuatus, $E$. handelii), Grimmia pitardii, $G$. mesopotamica, 16 (!) species of Tortula, 4 Weissia, 3 Hydrogonium (H. ehrenbergii, $H$. arcuatum, $H$. mamatkulovii), Trichostomopsis aaronii, Anacolia webbii. The three latter genera are known in the former USSR only from Middle Asia.

The specificity (i. e. species, known in the former USSR only from this region) of the European part of the former USSR includes 55 species. This group is rather heterogeneous. Thirteen species are known only from North-West, especially from Kola Peninsula (Andreaea crassinervia, Bryum culmannii, B. murmanicum, B. savicziae, $B$. saxatile, B. tardum, B. tenuisetum, B. umbratum, Ditrichum zonatum, Pseudocalliergon angustifolium, Sanionia nivalis, Seligeria subimmersa, Warnstorfia $h$-schulzei). As it is clear from this enumeration, the specificity of the Kola Peninsula largely depends on better studies of Bryum and Drepanocladus-group. Twelve species are confined to the "West", 
and in reality - to the Carpatian Mts.: Barbula crocea, Campylopus schwarzii, Campylostelium saxicola, Ephemerum recurvifolium, E. sessile, Grimmia apiculata, Hypnum jutlandicum, Molendoa hornschuchiana, Pohlia ambigua, Rhytidiadelphus loreus, Tetrodontium ovatum, Weissia rostellata. Only 6 species are known only from Baltic republics, now countries (this region includes also Kaliningrad Province of Russia) - Tortella rigens, T. flavovirens, Schistidium trichodon, Orthodontium lineare, Bryum marratii, B. mamillatum. But some of them are known only by old and unconfirmed records. Most species of only European distribution within the former USSR are known in several regions near the western borders North-West, Baltic, West, Belorussia, in different combinations: Bryum klinggraeffii, B. violaceum, Cinclidotus danubicus, Cynodontium suecicum, Dicranodontium asperulum, Encalypta mutica, Fissidens fontanus, F. rufulus, Physcomitrium arenicola, etc. The only four species, confined to European part of the former USSR are more or less widely distributed on its territory (Cyrto-hypnum minutulum, Sphagnum molle, Pseudephemerum nitidum, Ephemerum serratum).

The peculiarity of Caucasus appears to be less than could be expected, 30 species, but among them there are many interesting, well-known by their "revealing" distribution: Anomodon rostratus, Bartramia stricta, Bryohaplocladium virginianum, Crumia latifolia, Cryphaea heteromalla, Encalypta microstoma, Epipterygium tozeri, Eurhynchium pumilum, Hookeria acutifolia, Leptobarbula berica, Philonotis rigida, Ptychomitrium incurvum, Rhynchostegiella teesdalei, Taxiphyllum densifolium.

So, the peculiarities of European part of the former USSR and Caucasus seem rather poor if they are considered alone. However, if to combine these regions, their specificity appears to be much more considerable, and exceeds the number of species confined to Far East (and even Far East + South Siberia) - 156 species. The species common for both European part of the former USSR and Caucasus (absent in the other parts of ex-USSR) are: Anacamptodon splachnoides, Antitrichia curtipendula, Atrichum angustatum, Aulacomnium androgynum, Brachydontium trichoides, Buxbaumia viridis, Campylopus flexuosus, C. fragilis, Cinclidotus aquaticus, Cirriphyllum tommasinii, Diphyscium foliosum, Eurhynchium crassinervium, E. flotovianum, E. striatulum, Fissidens rivularis, Heterocladium heteropterum, Hookeria lucens, Hygroamblystegium fluviatile, Isothecium alopecuroides, I. myosuroides, Leptodon smithii, Metaneckera menziesii, Neckera complanata, N. crispa, N. pumila, Plagiomnium undulatum, Plagiothecium plathyphyllum, $P$. undulatum, Pogonatum aloides, P. nanum, Pseudoleskea saviana, Pterogonium gracile, Ptychodium plicatum, Racomitrium affine, $R$. elongatum, $R$. macounii ssp. alpinum, Rhynchostegiella tenella, Rhynchostegium murale, $R$. rotundifolium, Scorpiurium circinatum, Sporledera palustris, Thamnobryum alopecurum, Tortula latifolia, T. papillosa, T. vahliana, Ulota coarctata.

However, the number of genera limited to Europe and Caucasus is, nevertheless, smaller, than that of the Far East. These are 20: Campylostelium, Ephemerum, Orthodontium, Pseudephemerum, Crumia, Epipterygium, Cryphaea, Hookeria, Leptobarbula, Rhynchostegiella, Antitrichia, Brachydontium, Diphyscium, Leptodon, Metaneckera, Pterogonium, Ptychodium, Rhynchostegium, Scorpiurium, Sporledera (in Far East - 27, or if one counts the genera for Far East + South Siberia - 31).

The further addition to this group of generally European species can be made by 44 species known from Europe + Caucasus + Middle Asia (ambiguous and critical taxa are not listed): Acaulon triquetrum, Barbula enderesii, Bartramia halleriana, Brachythecium geheebii, Camptothecium lutescens, Cinclidotus fontinalioides, Dicranoweisia cirrata, Didymodon tophaceus, Encalypta spathulata, Entostodon fascicularis, Eurhynchium speciosum, Fissidens crassipes, F. exiguus, Grimmia crinita, $G$. orbicularis, Herzogiella seligeri, Homalothecium aureum, H. philippeanum, H. sericeum, Hypnum imponens, Orthotrichum diaphanum, $O$. lyelii, $O$. patens, $O$. tenellum, Palamocladium euchloron, Pleurochaete sqaurrosa, Pottia 
bryoides, Pseudoscleropodium purum, Rhynchostegium megapolitanum, Schistidium flaccidum, Tortula canescens, $T$. handelii, $T$. inermis, $T$. intermedia, $T$. lingulata, $T$. ruraliformis, $T$. subulata, $T$. virescens. Also, there are 12 species known in the former USSR only for Caucasus and Middle Asia, the most of them, however, are known also in the Mediterranean part of West Europe: Crossidium crassinerve, C. griseum, Encalypta intermedia, Entostodon pallescens, Fabronia pusilla, Fissidens grandifrons, Funaria aequidens, Leucodon immersus, Phascum vlassovii, Pleuroweisia schliephackei, Tortula atrovirens, T. princeps.

In the Arctic there are 31 species known in the former USSR only from this region. However, most of these taxa need further study. The most interesting are *Didymodon subandraeoides, Funaria polaris, *Pseudoleskea chilensis, *Rhizomnium gracile, *Seligeria oelandica, *Sphagnum arcticum, Arctoa anderssonii, *Heterocladium procurrens, Plagiothecium berggrenianum, Schistidium tenerum, *S. cryptocarpum, Voitia hyperborea, and Geheebia gigantea, the latter represents the only genus, specific for Arctic region in the territory discussed (but it occurs outside the Arctic in the mountains of Central Europe, Himalayas, Japan and Rocky Mts. of North America). Among the species enumerated above, there is a considerable number, known so far only from the Beringian Arctic (marked by *), which is the best explored part of the Russian Arctic.

However, if one considers the arctic region in a somewhat broadened sense, including species known also from the neighboring regions (Kola Peninsula, Polar Ural Mts., Putorana Plateau), the group of arctic species can be supplemented with Andreaea blyttii, A. nivalis, Aongstroemia longipes, Aplodon wormskjoldii, Brachythecium coruscum, B. udum, Bryum axel-blyttii, Calliergon megalophyllum, Cinclidium latifolium, C. subrotundum, Dicranum angustum, Distichium hagenii, Funaria arctica, Hamatocaulis lapponicus, Hypnum subimponens, Kiaeria glacialis, Molendoa tenuinervis, Oligotrichum falcatum, Orthotrichum pylaisii, Plagiomnium medium ssp. curvatulum, Pseudocalliergon brevifolius, Psilopilum cavifolium, Racomitrium ericoides, Sanionia orthothecioides, Schistidium andreaeopsis, Tortella arctica, etc.

The negative specificity (species occurring in all other main regions except this) of the above mentioned regions is as follow. There are practically no "negative species" for Siberia and Europe, exept Brachythecium trachypodium for Siberia and Trachycystis ussuriensis for Europe. Rather moderate is the negative specificity of Caucasus, 13 species, and Far East, where there are no data about 22 species, known however from the all five other main divisions of the former USSR. However, these "negative" groups surely will be reduced by further collections.

The negative specificity of the Arctic is reasonably greater - 39 species, representing obvious southern elements (Atrichum flavisetum, A. undulatum, Brachythecium rutabulum, Bryum elegans, B. subelegans, B. uliginosum, Dicranella heteromalla, Didymodon vinealis, Eucladium verticillatum, Eurhynchium hians, Fabronia ciliaris, Funaria muehlenbergii, Grimmia tergestina, Homalia trichomanoides, Hygroamblystegium tenax, Hypnum fertile, $H$. pallescens, Lescuraea mutabilis, Mnium heterophyllum, $M$. hornum, Orthodicranum flagellare, $O$. montanum, Orthotrichum affine, O. striatum, Physcomitrium pyriforme, P. sphaericum, Plagiothecium latebricola, Pohlia melanodon, Racomitrium heterostichum, Rhynchostegium riparioides, Sphagnum palustre, Splachnum ampullaceum, Timmiella anomala, Tortula laevipila, T. sinensis, Ulota crispa, Weissia brachycarpa, $W$. controversa).

But the greatest number of negative specificity is in the Middle Asia - 76 species (Aulacomnium turgidum, Blindia acuta, Brachythecium latifolium, Bryum cryophilum, B. imbricatum, Buxbaumia aphylla, Callicladium haldanianum, Calliergon richardsonii, Campylium chrysophyllum, $C$. halleri, $C$. hispidulum, C. sommerfeltii, Catoscopium nigritum, Cinclidium arcticum, Cynodontium polycarpon, C. strumiferum, Cyrtomnium hymenophylloides, Dichodontium pellucidum, Dicranella cerviculata, $D$. grevilleana, $D$. 
rufescens, D. schreberiana, Dicranodontium denudatum, Dicranum fuscescens, D. majus, Ditrichum cylindricum, D. pusillum, Encalypta brevicollis, E. procera, Grimmia incurva, G. muehlenbeckii, Hamatocaulis vernicosus, Heterocladium dimorphum, Hydrogrimmia mollis, Hylocomiastrum pyrenaicum, Hypnum callichroum, $\boldsymbol{H}$. recurvatum, Isopterygiopsis muellerana, Kiaeria falcata, $K$. starkei, Meesia longiseta, M. triquetra, Neckera pennata, Oligotrichum hercynicum, Plagiothecium cavifolium, P. piliferum, Pohlia drummondii, $P$. proligera, Polytrichum formosum, $P$. longisetum, $P$. sexangulare, Pseudocalliergon lycopodioides, $P$. trifarium, Racomitrium aciculare, $R$. fasciculare, $R$. lanuginosum, $R$. sudeticum, Rhytidiadelphus squarrosus, $R$. subpinnatus, Sphagnum angustifolium, $S$. balticum, $S$. compactum, $S$. cuspidatum, $S$. fallax, S. fimbriatum, S. imbricatum, $S$. $o b-$ tusum, S. papillosum, S. riparium, S. rubellum, Splachnum rubrum, Tayloria lingulata, Thuidium delicatulum, Timmia austriaca, Tomentypnum nitens). This enumeration clearly indicates the poority in bogs and wetlands, at least in the area investigated.

THE RELATIONSHIP OF THE MOSS FLORA OF THE REGIONS OF FORMER USSR WITH EACH OTHER

As it was shown above (Table 2), there are five regions within the former USSR where the number of species exceed 500 . They are European North-West, European West (most of Ukraine and Moldova), Caucasus, South Siberia and southern part of Far East. In Table 3 are represented the percentage of species in common among each of these five regions, and also Beringian Arctic, with each other regions (number of species in common : number of species in the latter region) ${ }^{l}$ :

Some considerations can be drawn from

\footnotetext{
1 - this simpliest coefficient is selected here because it is not affected by differences in number of species in bryofloras, if consider the values within the single serie (i.e. in relation to one, selected bryoflora - for example $S I B: S$ has $67.8 \%$ in common with $E U R: W$ ( 572 species) and nearly the same value, $71.7 \%$, with $E U R: B L R(334$ species); or $85.3 \%$ with $A R C$ : EURO (361) and $85.2 \%$ with $A R C$ : WS (237), etc;); the values of different series, however, are uncomparable.
}

this table by looking at the decreasing of percentage in each column:

1) European North-West has a rather high percentage $(>80 \%)$ with most regions, except European West, Crimea (Krym), Caucasus, Middle Asia, South Siberia and southern Far East (72.3 - $59.8 \%$ );

2) European West has a rather strong species relation $(>85 \%$ ) with nearby European subdivisions (Central Russia, Belorussia, Baltia, Krym) and also European East, South Ural and Western Siberia. The percentage of species in common is gradually decreases in relation to place farther away (North Ural - $81.4 \%$, European North-East $78.3 \%$, Caucasus - 77.4\%);

3) Caucasus also has a strong connections $(>84.8 \%$ ) with regions of southern and central parts of European ex-USSR: Krym, European West, Belorussia, Central Russia, European East, South Ural. It gradually decreases in the percentage of common species toward West Siberia $(83.2 \%)$, Baltia $(80.8 \%)$, North Ural $(80.7 \%)$, etc.;

4) South Siberia has a rather high relationship (> $80 \%$ ) with most of the regions, except the most oceanic (European NorthWest, Baltia, Belorussia, European West, Krym, Caucasus, southern Far East), and also with Middle Asia (despite the neighboring position of the latter);

5) Southern part of Far East has a weak relation with nearly all the regions, except West Siberia $(86.4 \%)$ and East Siberia $(82.0 \%)$. Even with neighboring Northern part of Far East $(75.7 \%$ ) and South Siberia $(67.3 \%)$ have only a rather weak relation with Southern Far East. The higher percentage for West and East Siberia can be explained by their rather poor and unspecific moss flora (mainly, as I understand, because of under-exploration);

6) Beringian Arctic is connected with other Arctic regions stronger than with any other $(80.4-83.6 \%)$, somewhat weaker with Northern Far East $(76.3 \%$ ) and so on.

These six relationships can be grouped into 2 natural patterns - some regions have stronger relations with $\mathrm{n}$ e a $\mathrm{r}$ b y regions/ weaker with remote, while other - stronger with relatively $r$ e $m$ o $t$ e regions (belonging 
Table 3. Percentage of species in common between regions of the former USSR (see also Figs. 4-9).

\begin{tabular}{|c|c|c|c|c|c|c|}
\hline \multirow{2}{*}{$\begin{array}{c}\text { Region } \\
\text { (in brackets - } \\
\text { number of species) }\end{array}$} & \multicolumn{6}{|c|}{ Percent of species in common with: } \\
\hline & EUR:NW & EUR:W & CAUC & SIB:S & FAR EAST:S & $\mathrm{ARC}: \mathrm{BE}$ \\
\hline \multicolumn{7}{|l|}{ ARC } \\
\hline EURO (361) & 90.0 & 70.7 & 72.6 & 85.3 & 70.4 & 80.7 \\
\hline WS (237) & 89.9 & 71.0 & 71.7 & 85.2 & 71.4 & 83.6 \\
\hline ES (371) & $\overline{82.7}$ & 64.3 & 68.5 & $\overline{83.0}$ & 62.2 & $\overline{80.4}$ \\
\hline BE (390) & 80.5 & 62.3 & 66.7 & 81.5 & 58.8 & 100 \\
\hline \multicolumn{7}{|l|}{ EUR } \\
\hline NW (554) & 100 & 74.5 & 74.4 & 72.9 & 59.9 & 56.7 \\
\hline NE (374) & 89.8 & 78.3 & 77.0 & $\underline{85.8}$ & 73.0 & 64.4 \\
\hline N-UR (311) & 93.9 & 81.4 & 80.7 & 91.6 & 76.5 & 74.6 \\
\hline B (453) & 85.7 & 86.3 & 80.8 & 71.3 & 64.0 & 47.2 \\
\hline BLR (334) & $\overline{85.3}$ & $\overline{94.6}$ & $\underline{88.0}$ & 71.7 & 70.1 & 45.8 \\
\hline$C(351)$ & $\overline{87.5}$ & $\overline{91.7}$ & $\overline{86.0}$ & 80.0 & 73.2 & 50.4 \\
\hline W (572) & $\overline{72.2}$ & $\underline{100}$ & $\overline{84.8}$ & $\overline{67.8}$ & 58.0 & 43.2 \\
\hline K (253) & 71.1 & 91.7 & 98.0 & 66.8 & 70.8 & 39.1 \\
\hline$E(243)$ & $\underline{85.2}$ & $\overline{97.5}$ & $\overline{96.3}$ & 86.4 & 77.8 & 57.6 \\
\hline S-UR (363) & $\underline{88.9}$ & 88.7 & $\underline{87.3}$ & 89.3 & 78.5 & 59.5 \\
\hline CAUC (627) & 64.8 & 77.4 & $\underline{100}$ & 64.0 & 53.4 & 41.5 \\
\hline \multicolumn{7}{|l|}{ SIB } \\
\hline W (286) & 93.7 & 83.6 & 83.2 & 93.4 & $\underline{86.4}$ & 69.9 \\
\hline$E(399)$ & 84.7 & 69.2 & 70.9 & 85.0 & 82.0 & 70.7 \\
\hline$S(560)$ & $\overline{72.3}$ & 67.5 & 71.6 & 100 & $\overline{67.3}$ & 58.6 \\
\hline \multicolumn{7}{|l|}{ FAR EAST } \\
\hline$N(321)$ & $\underline{87.2}$ & 73.2 & 72.9 & 85.0 & 75.7 & 76.3 \\
\hline$S(555)$ & $\overline{59.8}$ & 59.8 & 60.4 & 67.4 & $\underline{100}$ & 42.0 \\
\hline MID AS (489) & 59.3 & 67.3 & 76.3 & 66.9 & 50.1 & 43.4 \\
\hline
\end{tabular}

to the same zone)/ and weaker with nearby (belonging to another zone):

1) European West and Caucasus (Figs. 5 - 6) have stronger connections with n e a r b y regions, and a much weaker connections with more remote places; the South of Russian Far East (Fig. 8) probably also belongs to this group, but it has weak connections with any region of the former USSR, except West and East Siberia;

2a) European North-West (Fig. 4) and South Siberia (Fig. 7) have rather uniformly high correlations with many relatively $r$ e $m$ o $t$ e regions in the boreal and arctic zones, including $A R C$ : EURO, WS, ES, BE; EUR: NE, N-UR, C, E, S-UR; SIB: W, E : FAR
EAST: N. Other zone has less in common with European North-West and South Siberia; it includes the regions where deciduous forests are widespread: $E U R: B, B L R, W, K$; CAUC; MID AS; FAR EAST: S. It is usually considered as nemoral, or temperate. Though this zone is not so consistent as the boreal one, moss floras of its regions have rather much in common with each other, but often at the level higher than species. The main nucleus of this nemoral flora was discussed by Lazarenko (1944), when he analyzed the moss flora of the Soviet Far East;

2b) Beringian Arctic also has stronger connections with more re mote zonal arctic floras and weaker - with nearby 


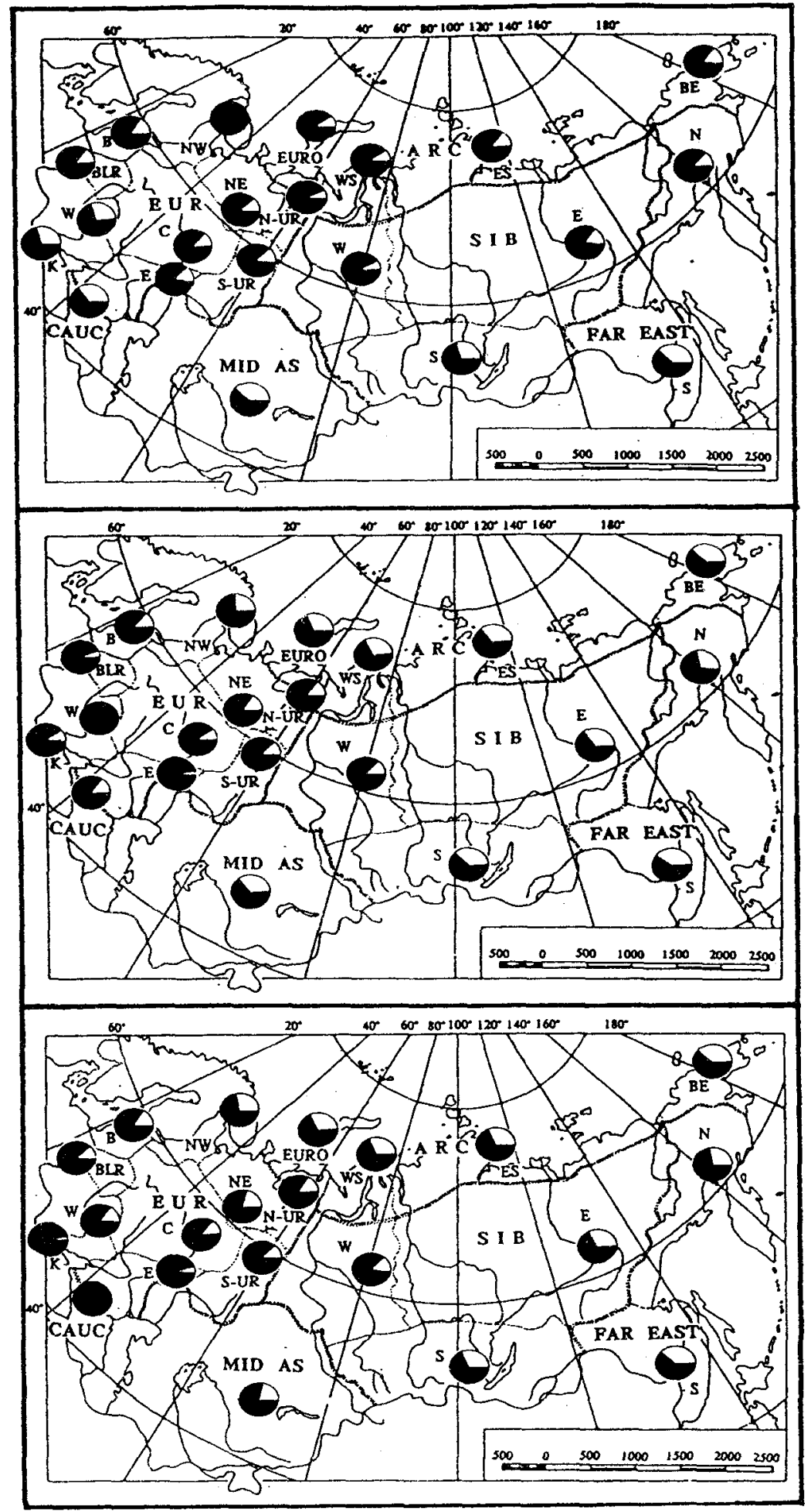

Figs. 4 - 6. Percent of moss species in common with moss flora of (4) European North-West, (5) European West, (6) Caucasus. See also Tab. 3. 


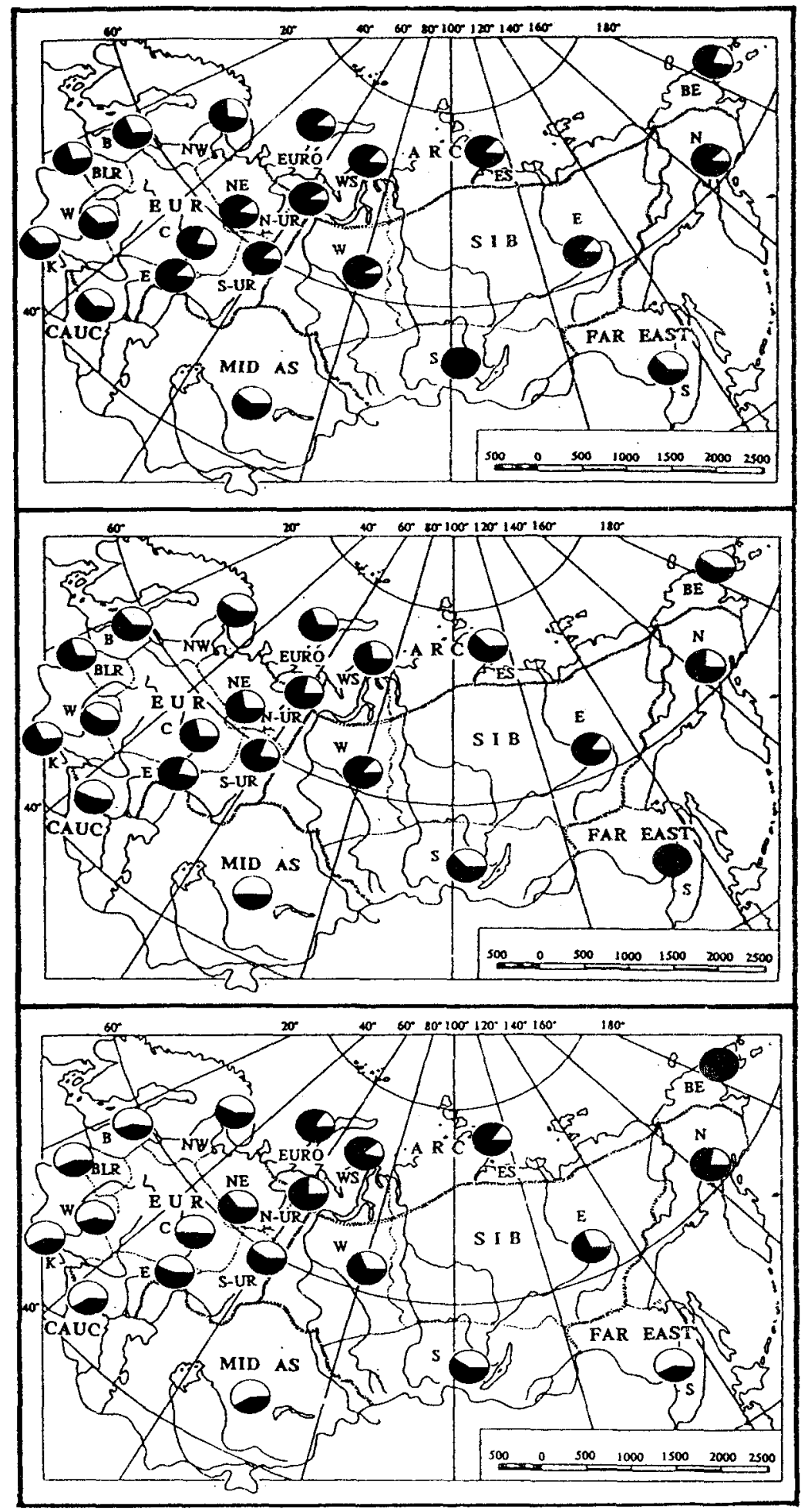

Figs. 7 - 9. Percent of moss species in common with moss flora of (7) South Siberia, (8) southern Russian Far East, (9) Beringian Arctic. See also Tab. 3. 
boreal floras. The fact that arctic floras have the high percentage of similarity with $E U R$ : $N W$ and SIB: $S$ means just that most of the arctic environmental diversity is represented in these two regions, where mountains occupy a considerable territories. Therefore, delimitation of Arctic zone from Boreal zone is based on its rather negative specificity.

Summarizing, three zonal types of moss floras can be segregated, basing on above analysis: Arctic, Boreal and Nemoral, or Temperate. It is important, however, that nearly a half of species of boreal floras have very wide ranges of distribution, well exceeding the Holarctic. So, despite the fact that moss floras of the most part of the former USSR are classifying as boreal, the number of really boreal species, more or less strongly limited to boreal biota, is rather low.

\section{ELEMENTS OF BRYODIVERSITY}

After the above overview we can try to expand on the moss diversity across the territory of the former Soviet Union (Fig. 2) and group moss species into a number of elements (which are illustrated by some characteristic species on Figs. 10-49). The most of them can be classified into four groups:

I. Widespread throughout the former USSR;

II. Alpine and mountain species;

III. "Circum-zonal species", limited in their geographical distribution to some zone (arctic, boreal, nemoral (temperate), arid), but occurring within these zones more or less evenly throughout the Holarctic or Eurasia;

IV. Western and Eastern species, limited in their range or strongly preferring one of oceanic sides of Eurasia.

I. WIDESPREAD SPECIES of average conditions of forest zone form a medium, which makes most of moss floras of all the territories to be of no less than 100-150 species rich, except some xeric areas of the South-East Europe (region of the Lower Volga River), Middle Asia, some parts of Eastern Caucasus. Most of species of this group occur also in tundra, though some of them are not so common there. In total, about 200 species.

Examples: Abietinella abietina, Brachythe- cium rivulare, Bryoerythrophyllum recurvirostrum, Cratoneuron filicinum, Dicranum scoparium, Drepanocladus aduncus, Leskeella nervosa, Orthotrichum obtusifolium, $O$. speciosum.

II. Montane AND Alpine SPECIES - this group includes species of different vegetational zones, but obviously limited in their distribution to mountains (with somewhat broader distribution in oceanic climates). The explanation of their range obviously relate to more diverse and in average more mild climatic conditions, favouring the surviving of these species, which are considered as relicts in many areas. In total, about 100 species.

Examples: Aongstroemia julacea, A. orientalis, Campylopus schimperi, C. schwarzii, Arctoa fulvella, Hylocomiastrum umbratum, Loeskeobryum brevirostre, Andreaea obovata, Amblyodon dealbatus, Tetrodontium repandum, Bryoerythrophyllum inaequalifolium, Plagiobryum zieri, Coscinodon cribrosus, Cnestrum schistii (Figs. 10-12).

\section{Circum-zonal species.} SPECIES.

III. A. ARCTIC AND ARCTO-ALPINE

III. A. 1. A r c t i c s e c i e s, confined in their distribution to the Arctic Floristic Province (Yurtsev \& al., 1978) only, or occurring also in neighboring regions of Kola Peninsula, Polar Ural Mts., Putorana Plateau in Eastern Siberia. In total, ca. 50 species.

Examples: Plagiothecium berggrenianum, Schistidium tenerum, Voitia hyperborea, Aplodon wormskjoldii, Cinclidium latifolium, C. subrotundum, Dicranum angustum, Hamatocaulis lapponicus, Kiaeria glacialis, Oligotrichum falcatum, Pseudocalliergon brevifolius, Psilopilum cavifolium, Schistidium andreaeopsis (Fig. 15).

III. A. 2. A r c to-A l pi n e s p ci e s. The well-known pattern. It is, important to note are that the considerable part of species, typically growing in high mountains above timber-line, occur sporadically in same mountains on lower altitudes in deep canyons, on cliffs, and so on. In total, about 100 species.

Examples: Dicranella subulata, Cono- 
stomum tetragonum, Andreaea rupestris, Bartramia ithyphylla, Desmatodon latifolius, Dicranoweisia crispula, Lescuraea saxicola. Orthothecium chryseon, Paraleucobryum enerve, Polytrichastrum alpimim, Racomitrium lanuginosum, Sarmeritypnum sarmentosum (Figs. 13-14).

III. B. BOREAL SPECIES. Though traditionally the main part of species in fioras of boreal zone was considered as boreal, I think that the number of species with sistribution more or less confined to boreal zone is probably no more than 30 .

Examples: Tetraphis pellucida, Tetraplodon angustatum, Splachnum rubrum, S. ampullaceum, Buxbaumia aphylla, Schistostega pennata, Rhytidiadelphus subpinnatus, Brachythecium oedipodium (Figs. 16-18).

III. C. PAN- OR Eurasian Nemoral (temperate) species have usually the latitudinal northern limit, at about $58-62^{\circ} \mathrm{N}$. In total, about 70 species.

Examples: Homalia trichomanoides, Dicranum viride, Anomodon longifolius, Dicranella heteromalla, Callicladium haldanianum, Atrichum undulatum s.l., Fissidens taxifolius, Eurhynchilum angustirete, E. hians, Platygyrium repens (Figs. 19-21).

III. D. XERIC SPECIES are mostly confined in the former USSR to the desert zone of Middle Asia, but some species have wider distribution, penetrating to steppe and forest zones by xeric rocky slopes and other suitable habitats. In total, ca. 70 species.

Examples: Tortula atrovirens, T. handelii, $T$. inermis, $T$. pagorum, $T$. caninervis, Entostodon fascicularis, E. handelii, $E$. hungaricus, Crossidium squamiferum, C. crassinerve, Pterygoneurum ovatum, $P$. subsessile, Cirimmia tergestina, G. plagiopodia, G. pitardii, Aloina rigida, Anacolia webbii, Fabronia ciliaris (Figs. 22-24).

IV. OCEaniC SPECiEs. In zonal aspect most of the representalives of this group are a temperate species, but conirary to the previous circum-zonal group, these species are limited or strongy prefering one of the oceanic sides of Eurasia. Many species are comprising the classical disjuntions between Europe and Western North America, and between East Asia and Eastern North
America. These disjunctions need some comments. Usually lists of these bicentric disjuncts are carefully rectifying from species known from other regions, even by a single collection (c). Iwatsuki, 1992), Indeed, it is an important account. Bul here I'd like to underline more similarities between western sides of Eurasia and North America, as well as between eastern sides of both continents. Many species of formally tri- or polycentric distribution are very common in either Western North Anerica \& Europe, or Eastern North America \& East Asia, being much rarer in all the other regions. For example, Aulacomnium androgynum, isothecium myosuroides, Grimmia pulvinata are very common in Western North America and Europe, being very rare in the Easts of both Eurasia and North America. In parallel way Bryhnia novae-angliae, Grimmia pilifera are common species in Russian Far East, Japan and China and Eastern North America, but extremely rare or absent in Europe and Western North America. My conception of Wests and Easts in such broadened sense can be illustrated by pairs of Grimmia puivinatal $G$. pilifera (Figs. 46-47) and Hookeria lucens/ $H$, acutilobo (Figs. 48 . 49). In many cases Eastern (within Holarctic) species are widespread in tropical zone (cf. Herpetineuron toccoae), while Western - known from many regions of Southern Hemisphaere.

IV. A. WESTERN sPECWES. Diverse group, composed of at least four distinct subgroups. In total about 200 species.

IV. A. 1. European endemics or subendemics foccurring in neighboring North Africa and West Asia).

Examples: Cinclidotus danubicus, Cryphaea heteromalla. Eurhynchium pumilum, E. crassinervium, E. striatulum, Rhynchostegiella tenella, R. teesdalei, Cirriphyllum tommasinï, Neckera pumila, Scorpiurium circinatum, Brachythecium geheebii (Figs. 25-27).

IV. A. 2. A m phi-A $t$ an $t$ i c s pecies.

Examples: Anomodon rostratus, Anacamptodon splachnoides, Diphyscium foliosum, Neckera complanata, Homalothecium serice$u m$, and a very few others (Figs. 28-30). 


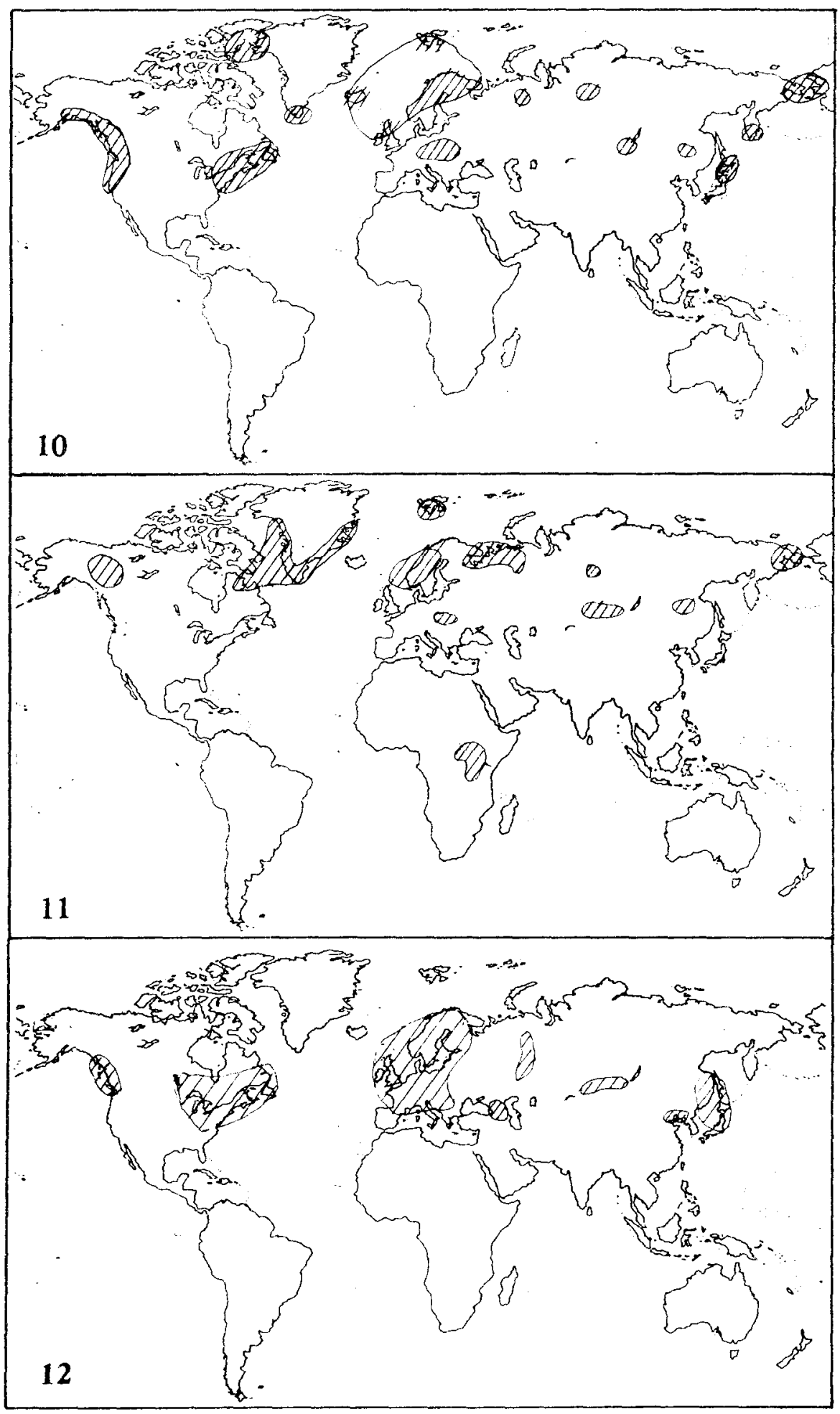

Figs. 10 - 12. Distribution of (10) Arctoa fulvella (in part after Schofield, 1972), (11) Andreaea obovata (after Murray, 1987, completed), (12) Hylocomiastrum umbratum (after Ochyra \& al., 1992b). 


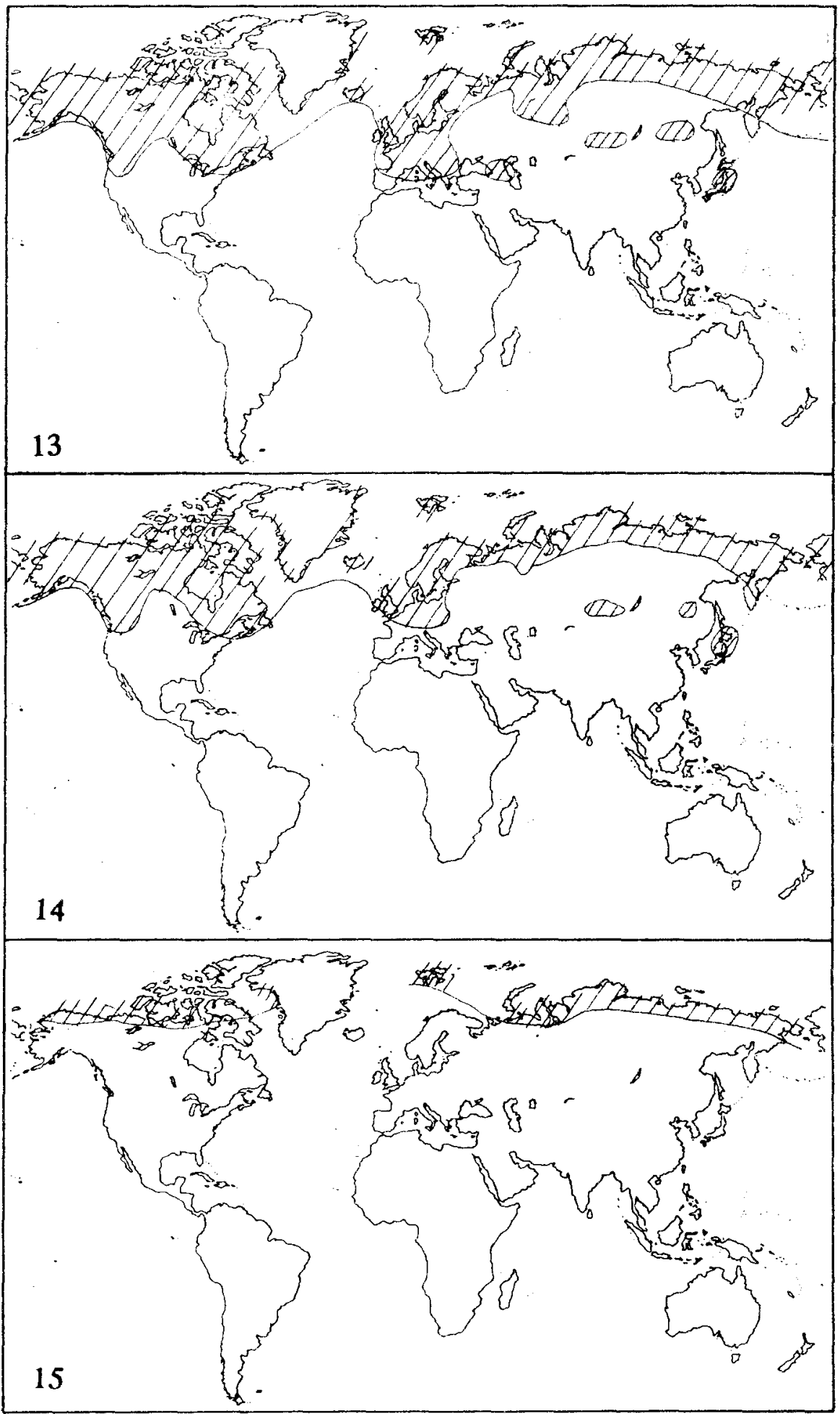

Fig.. 13 - 15. Distribution of (13) Dicranella subulata, (14) Conostomum tetragonum, (15) Plagiothecium berggrenianum (in part after Ireland, 1986). 


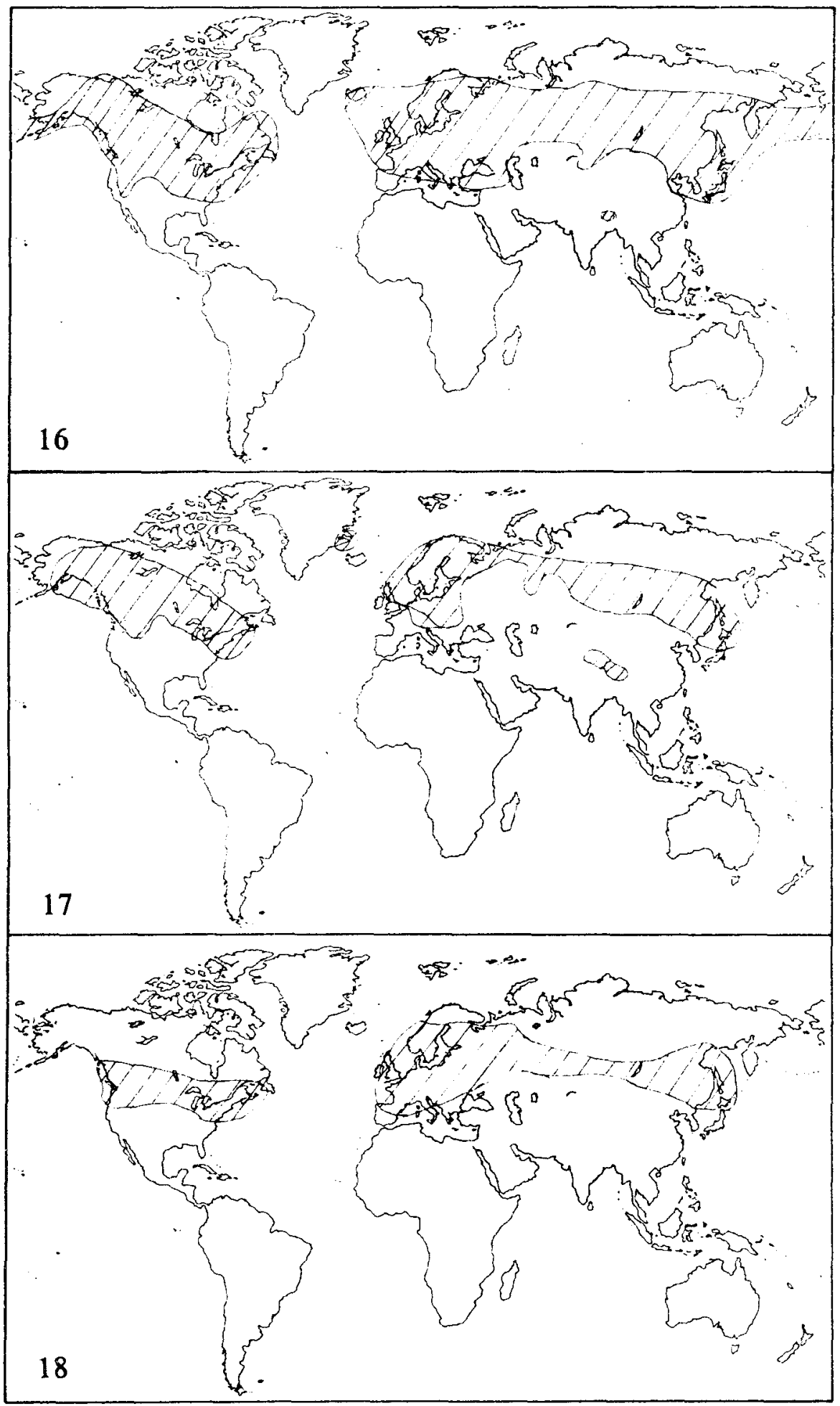

Figs. 16 - 18. Distribution of (16) Tetraphis pellucida (in part after Schofield, 1972), (17) Tetraplodon angustatum (after Szmajda \& al. 1991, completed), (18) Schistostega pennata. 


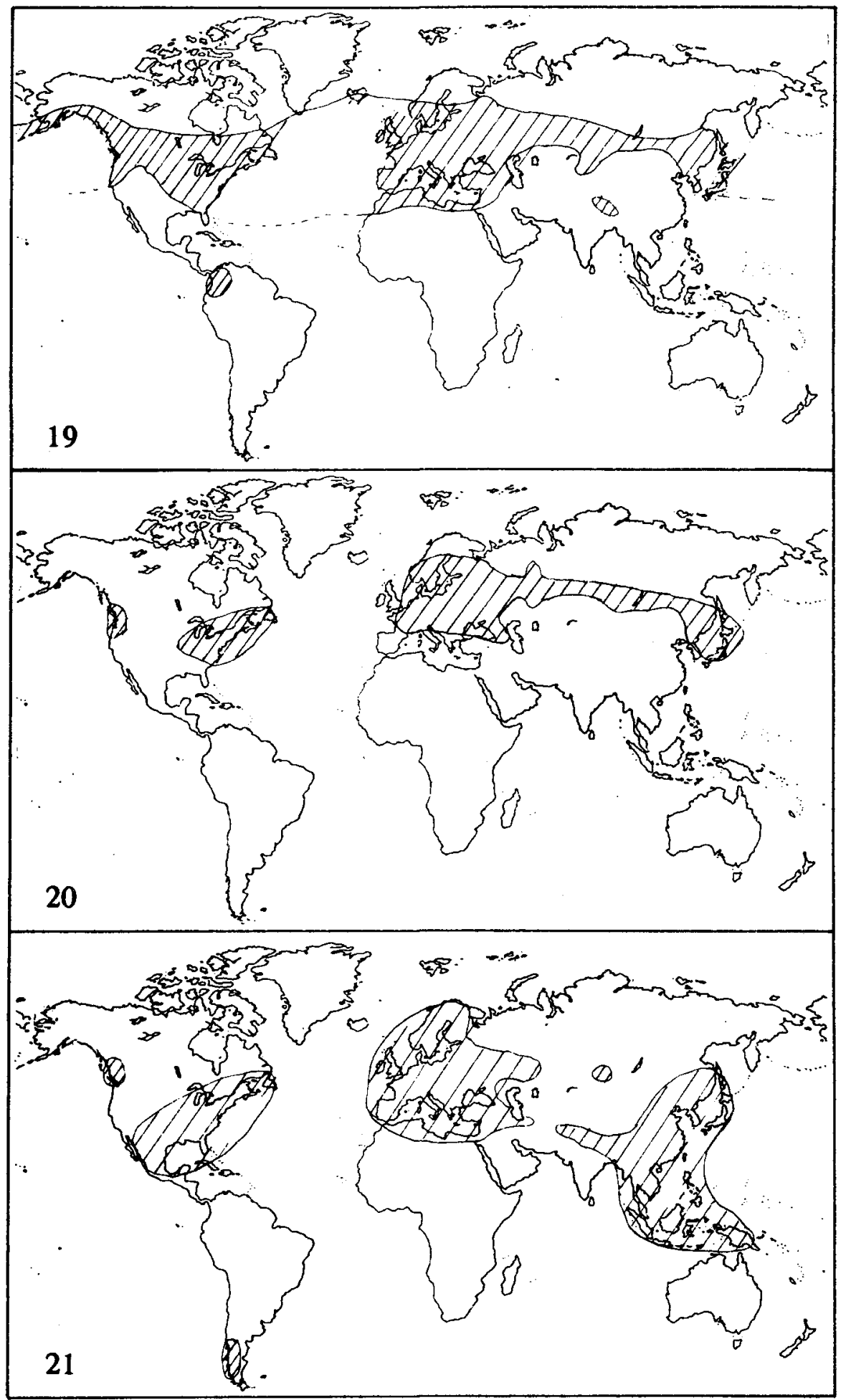

Figs. $19-21$. Distribution of (19) Dicranella heteromalla, (20) Callicladium haldanianum, (21) Fissidens taxifolius. 


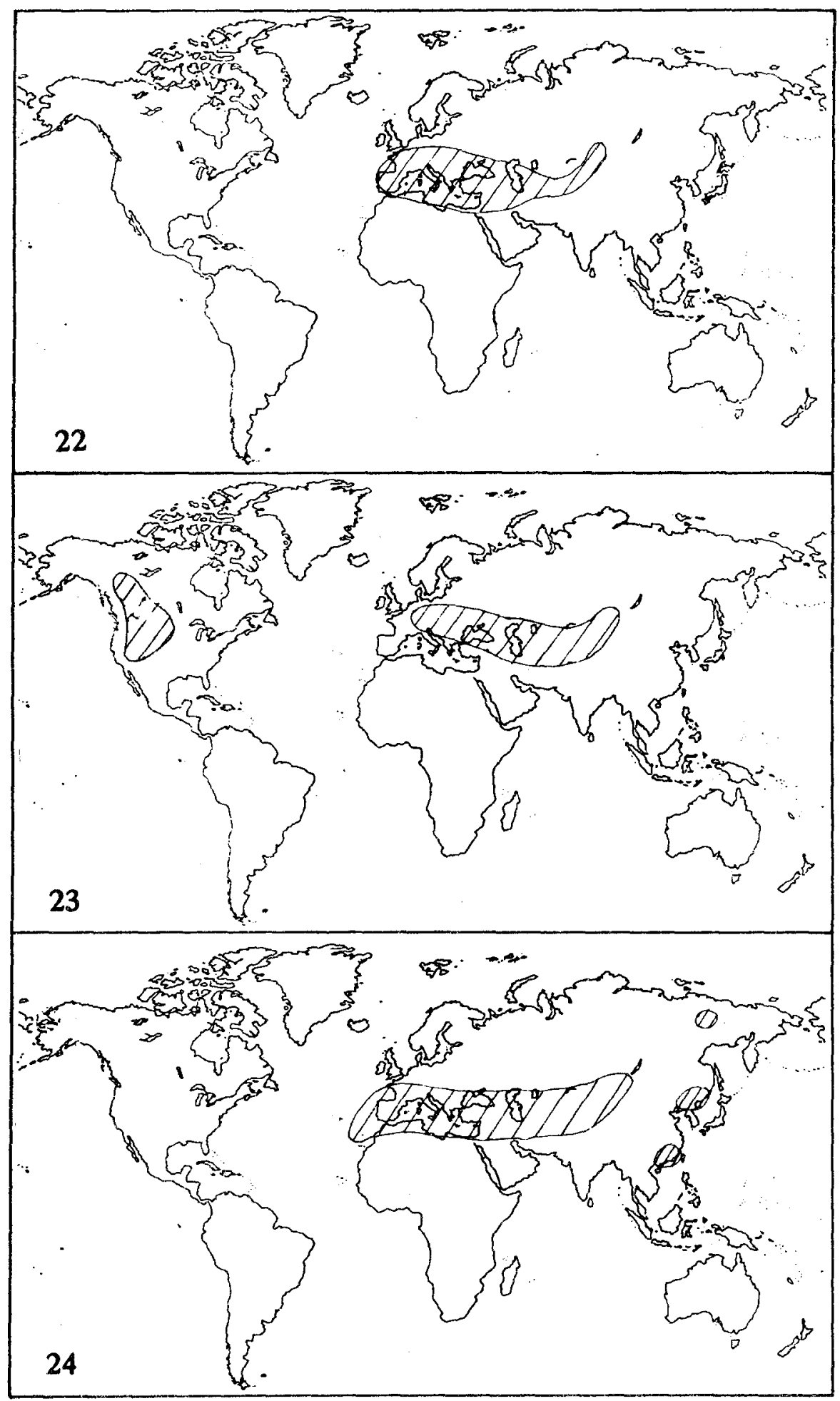

Figs. 22 - 24. Distribution of (22) Homalothecium philippeanum, (23) Grimmia plagiopodia, (24) Grimmia tergestina. 


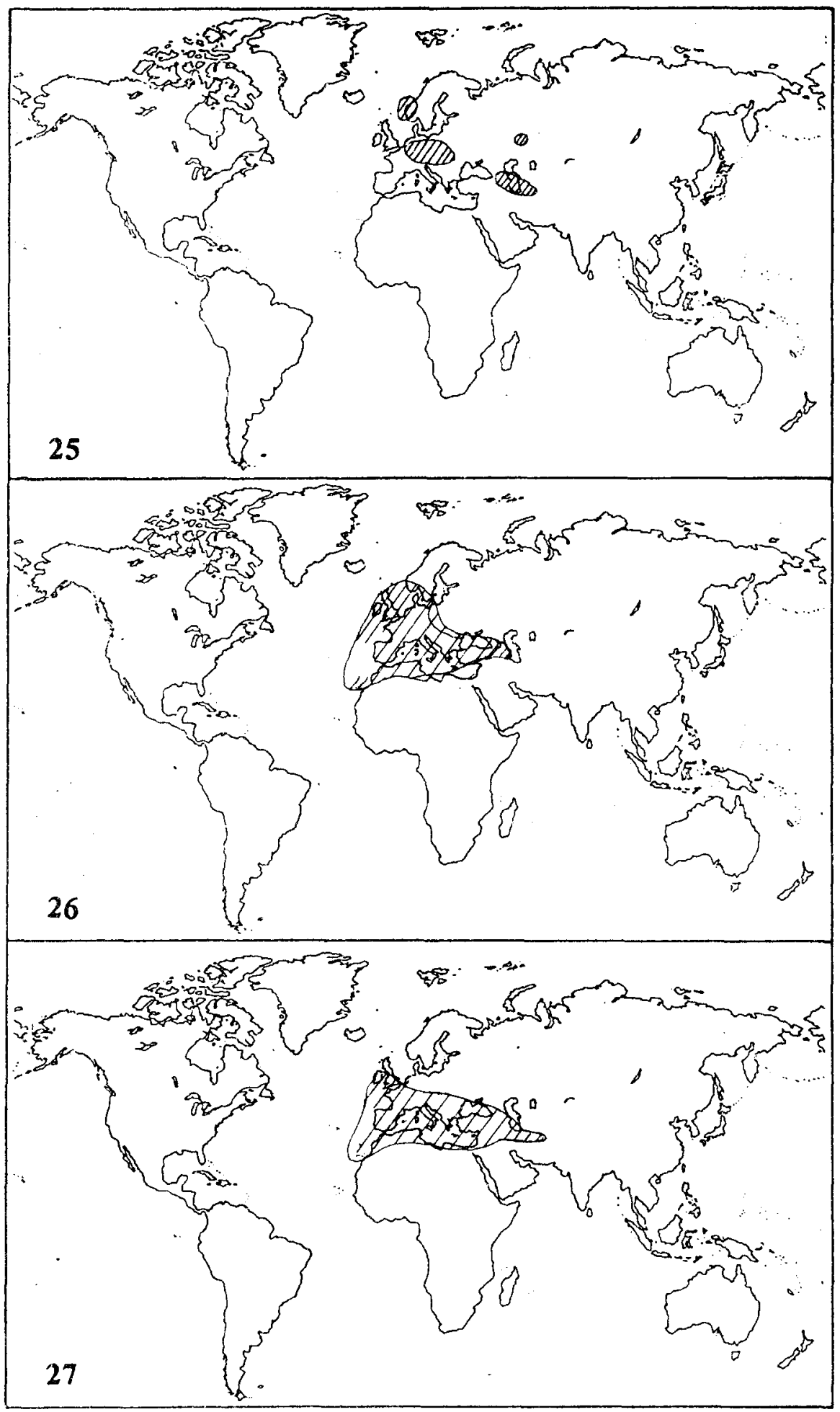

Figs. 25 - 27. Distribution of (25) Brachythecium geheebii (after Ochyra \& Szmajda, 1983, completed), (26) Eurhynchium pumilum (after Stoermer, 1969, completed), (27) Scorpiurium circinatum. 


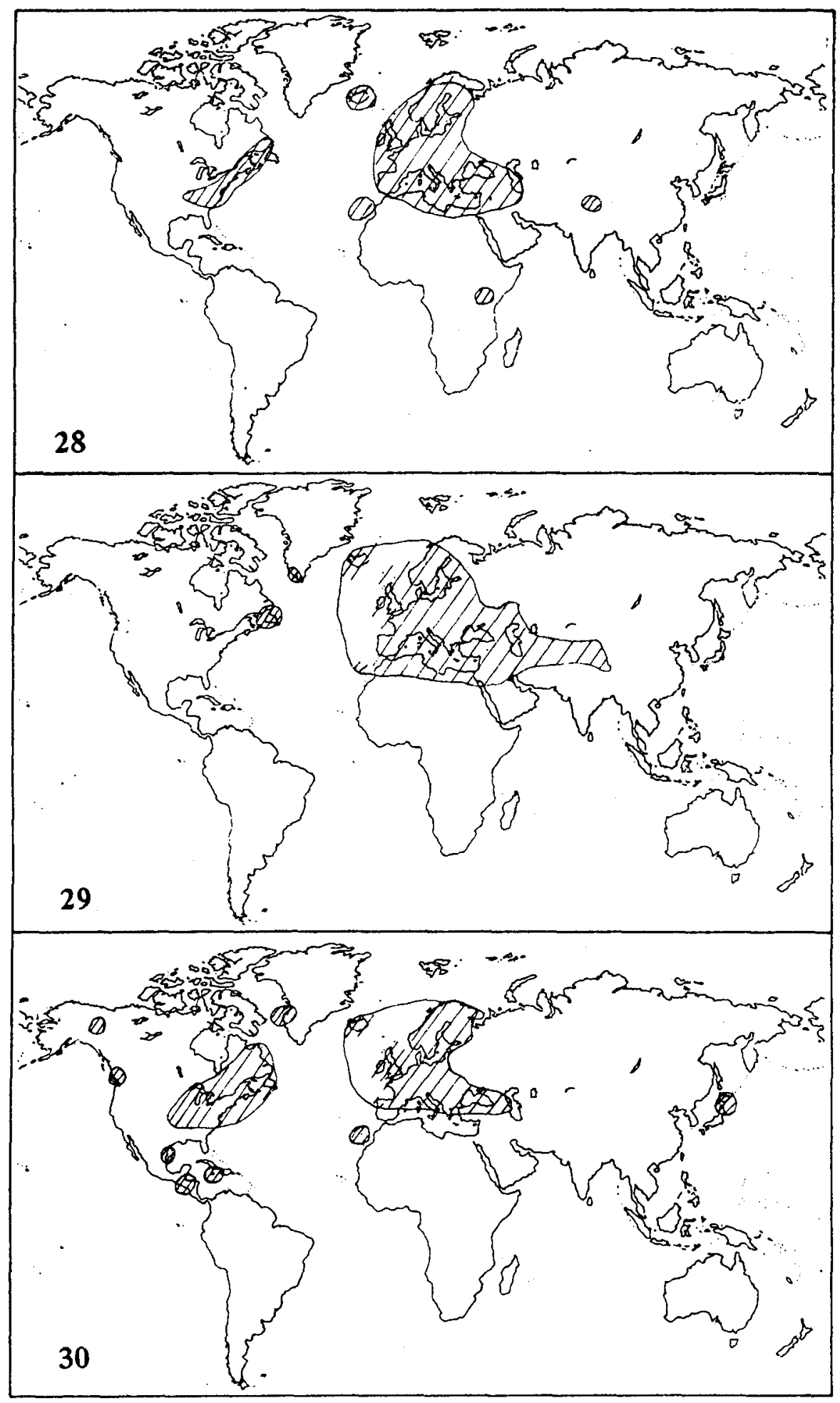

Figs. 28 - 30. Distribution of (28) Neckera complanata (after Ochyra \& al., 1988, completed), (29) Homalothecium sericeum, (30) Diphyscium foliosum (after Ochyra \& al., 1990, completed). 


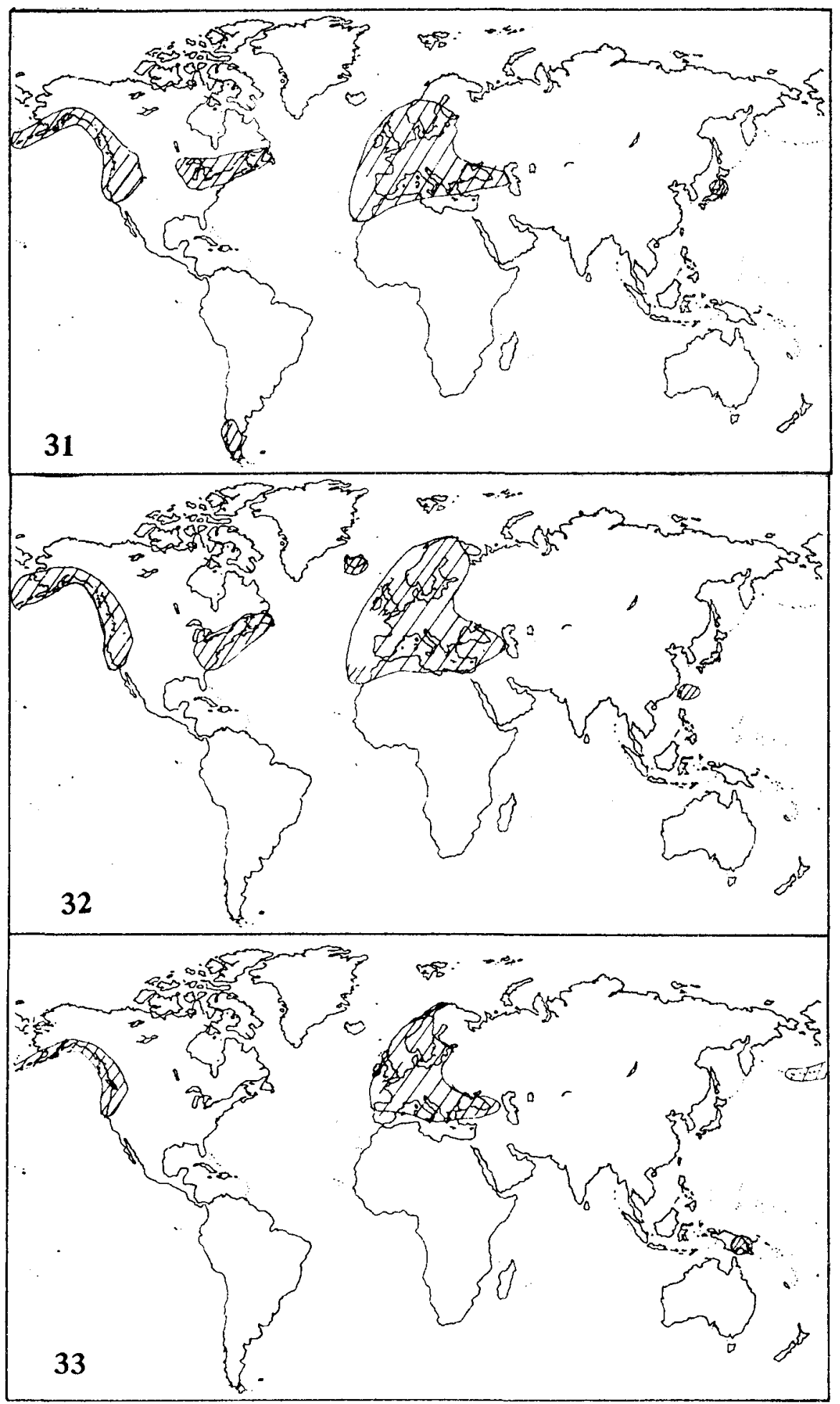

Figs. 31 - 33. Distribution of (31) Aulacomnium androgynum (in part after Stoermer, 1969), (32) Isothecium myosuroides (Stoermer, 1.c. and others), (33) Plagiothecium undulatum (after Ireland, 1986 and Ochyra \& al., 1990). 


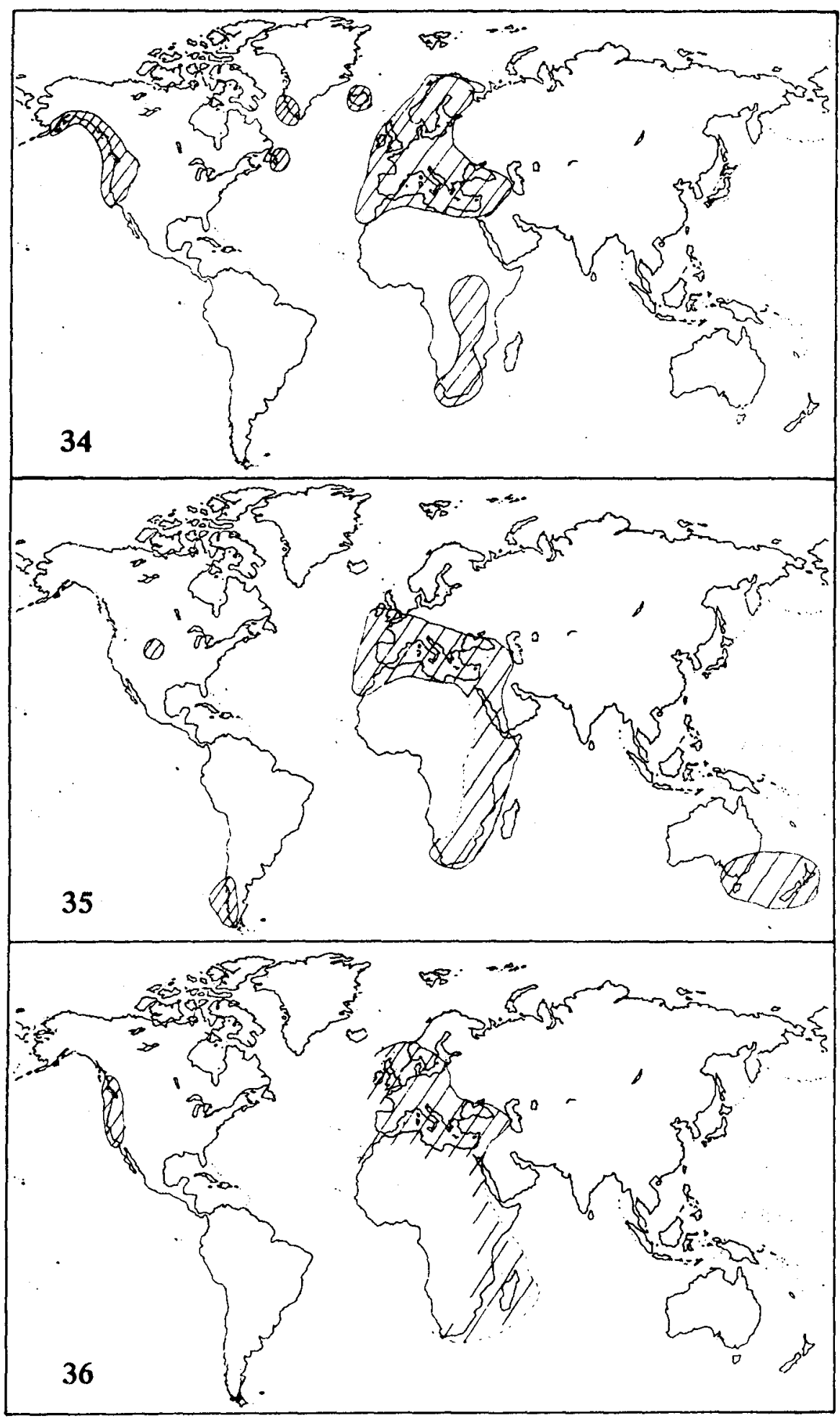

Figs. 34 - 36. Distribution of (34) Antitrichia curtipendula (in part after Schofield, 1972 and Stoermer, 1969, completed), (35) Leptodon smithii, (36) Pterogonium gracile (in part after Stoermer, 1969). 


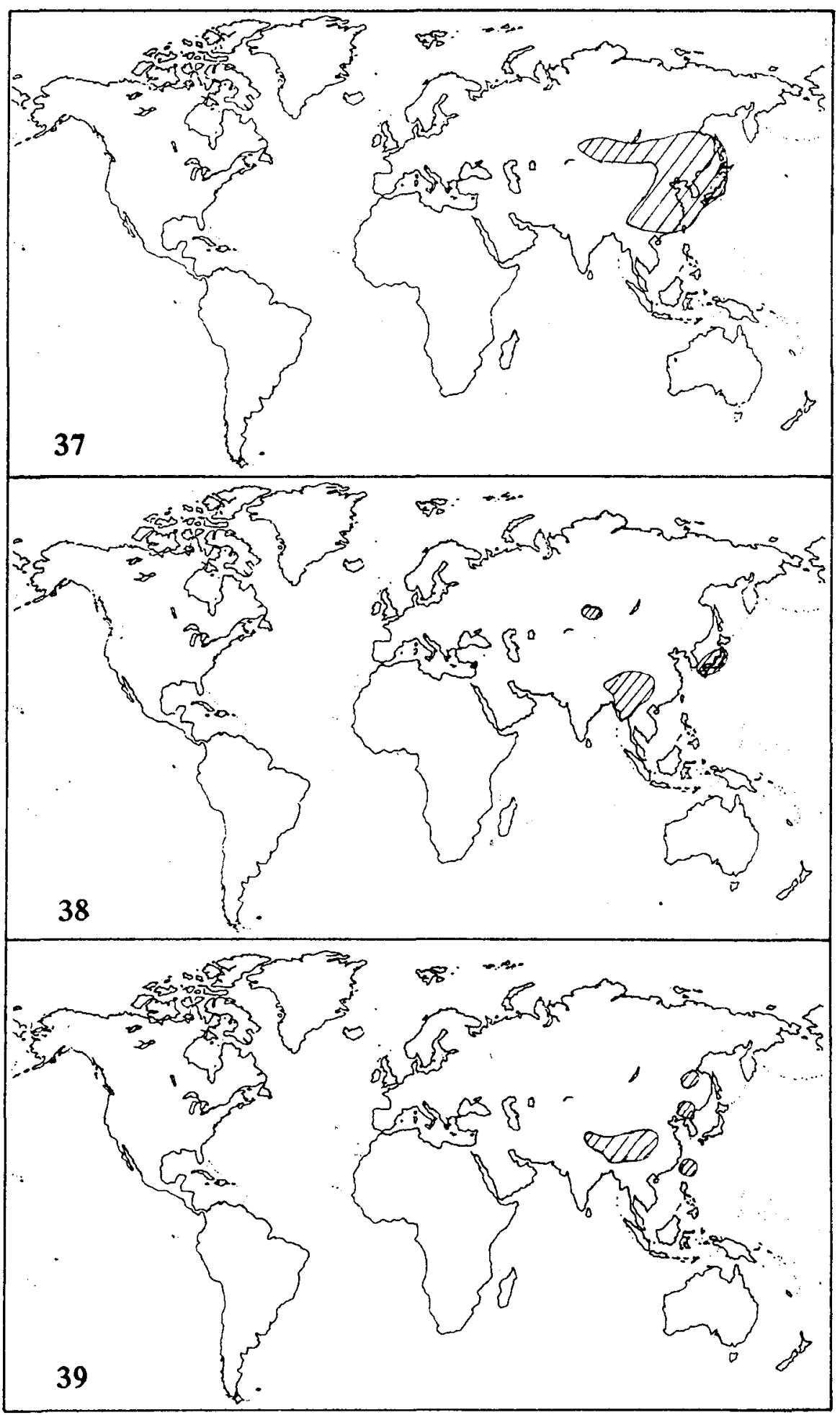

Figs. 37 - 39. Distribution of (37) Eurohypnum leptothallum (in part after Wu, 1992 and Abramov \& Abramova, 1983), (38) Brachythecium wichurae, (39) Actinothuidium hookeri (in part after Wu, 1992). 


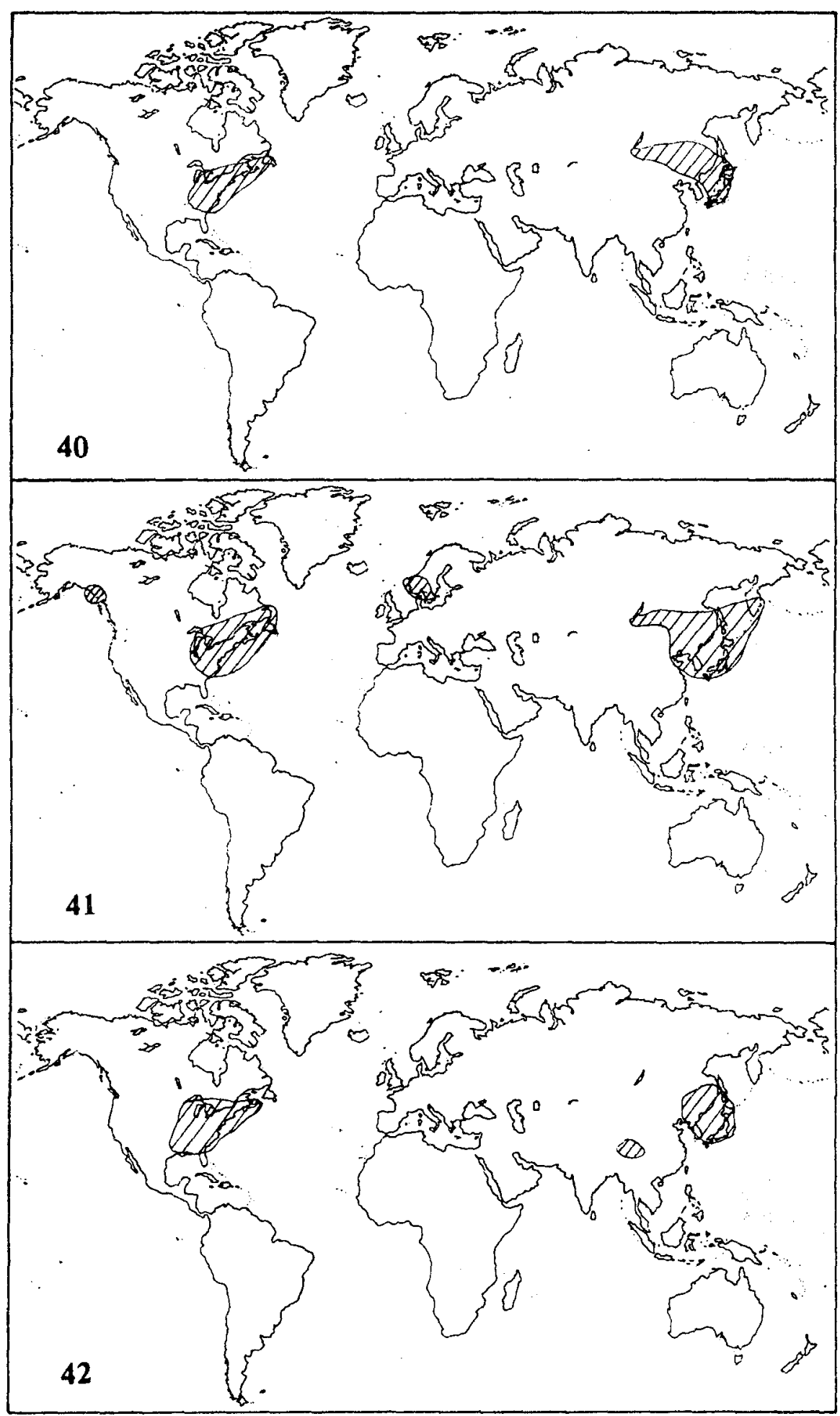

Figs. 40 - 42. Distribution of (40) Pylaisiadelpha tenuirastris, (41) Bryhnia nowae-angliae, (42) Aulacomnium heterostichum (after Janssens \& al., 1979). 




Figs. $43-45$. Distribution of (43) Oligotrichum parallelum, (44) Pleuroziopsis ruthenica, (45) Aulacomnium acuminatum. 


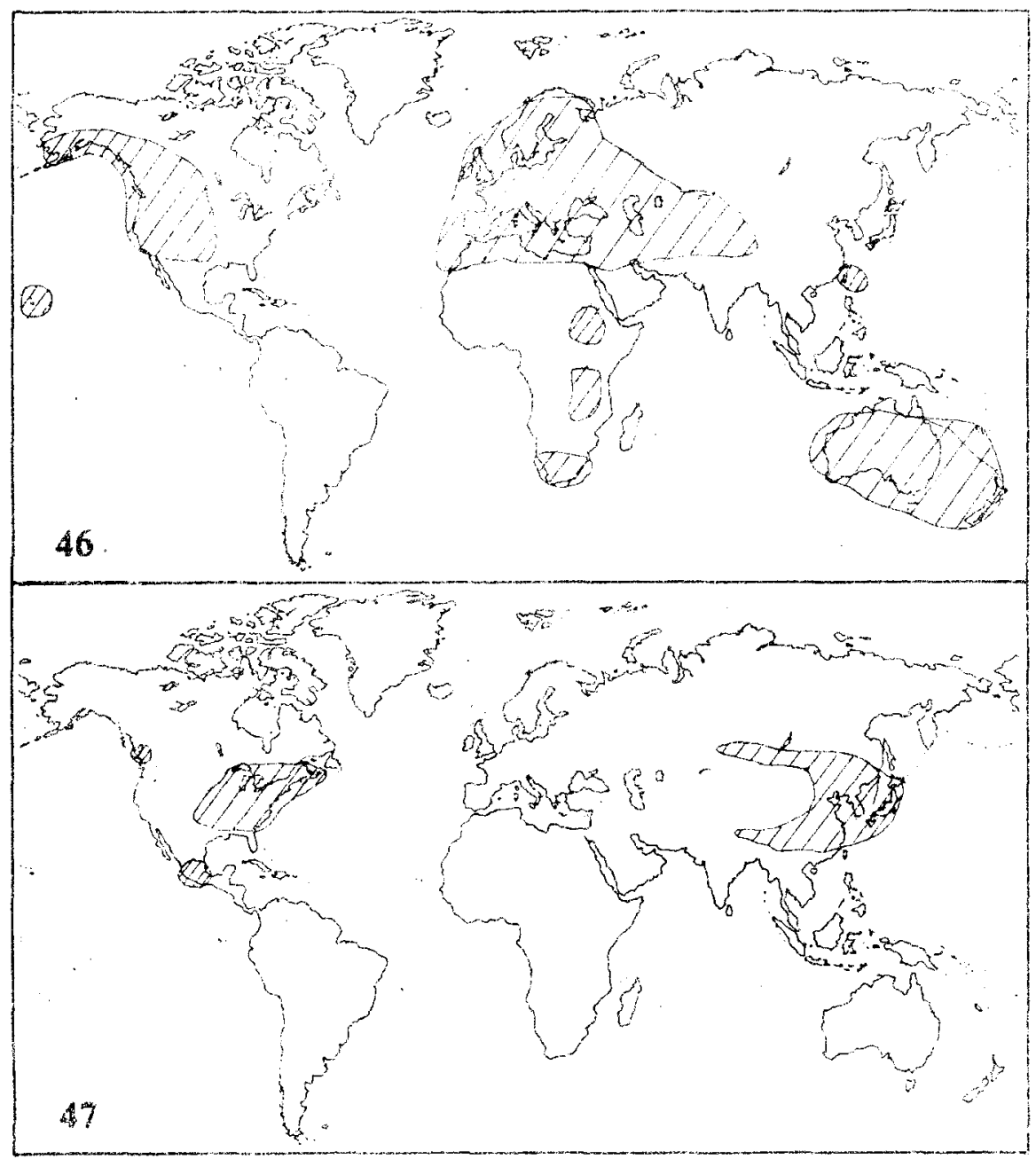

Figs. 46 - 47. Distribution of (46) Grimmia pulvinati, (47) Grimmia pilifera (after Iwatsuki, 1972 and Cao 8 Vitt, 1986, completed).

IV. A. 3. European-Western North American disjuncis

Examples: Dicranoweisia cirrata, Crumia latifolia, Buxbaumia viridis, Hookeria lucens, Metaneckera menziesii, Encalypta spathulata, E. mutica, Herzogiella seligeri, Orthotrichum lyellii (Figs. 31-33).

IV. A. 4. Widespread species, but in Holarctic their m a i n a rea $s$ are on the W e s $t$ of Eurasia (a) or on the Wests of Eurasia and North America (b)

Examples: (a) Philonotis rigida, Bartramia stricta, Leptodon smithii, Plagiomnium un . dulatum; (b) Aulacomnium androgynum, Plagiothecium undulatum, Bartramia hai leriana, Antitrichia curtipendula, Pterogonium gracile, Isothecium myosuroides
(Figs. 34-36).

IV. B. EASTERN SPECIES also represent at least four distinct groups. In total about 180 species.

IV.B. 1. East Asian Species. Examples: Actinothuidium hookeri, Fauriella tenuis, Dozya japonica, Climacium japonicum, Leucodon pendulus, Anacam. ptodon latidens, Eurohypnum leptothallum, Plagiothecium obtusissimum, Rhizomnium striatulum, R. parvulum, Pseudoleskeopsis zippellii (Figs. 37-39).

IV. B. 2. E a si Asian-Eastern Norih American disjuncis.

Examples: Aulacomnium heterostichum, Brothera leana, Buxbaumia minakatae, Ano- 


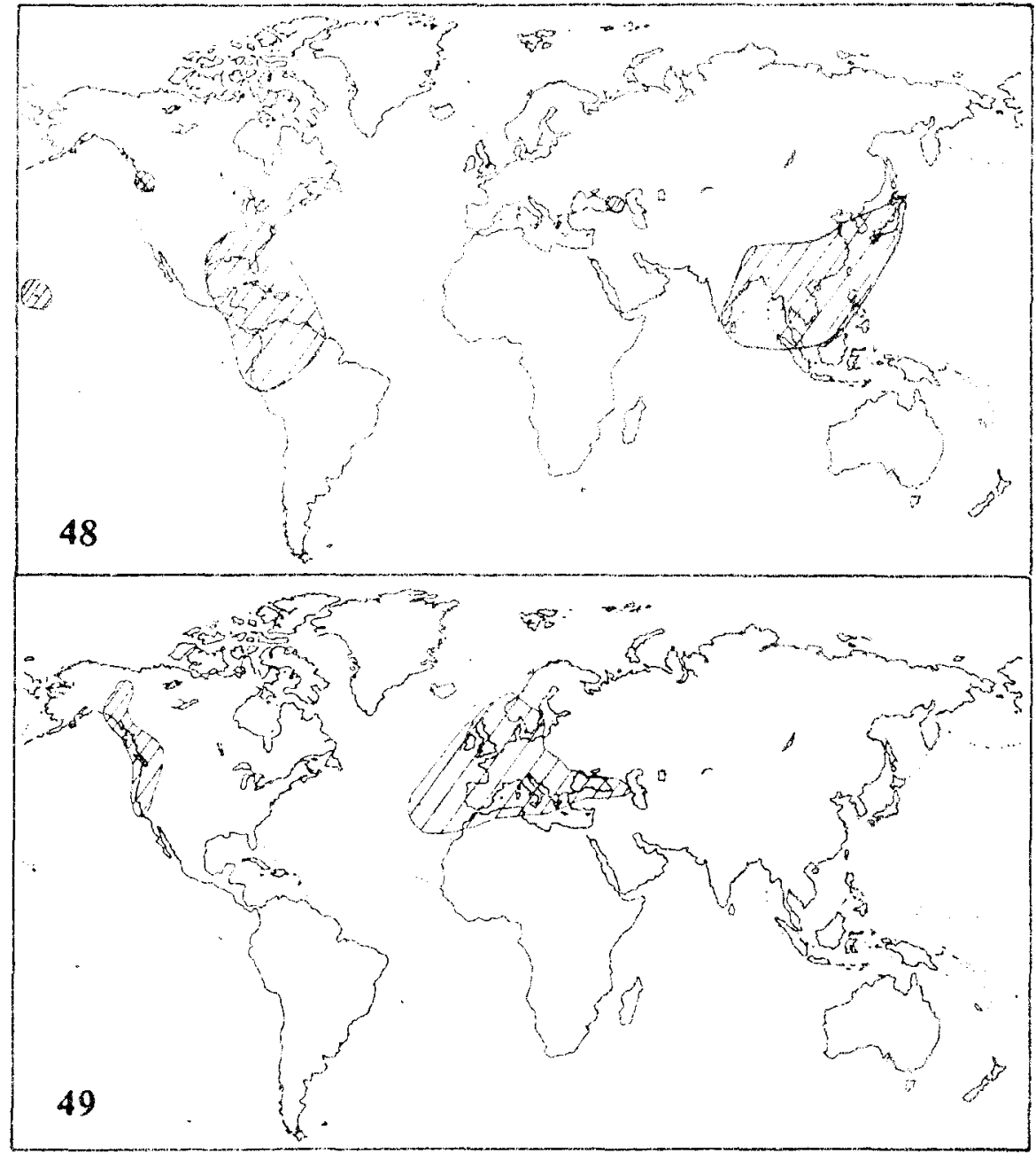

Figs. 48 - 49. Distribution of (48) Hookeria lucens (in part after Schofield, 1972 and Stosrmer, 1969), (49) Hookeria acutifolia (after Iwatsuki, 1972, completed).

modon minor, A. thraustus, Helodium paludosum, Entodon sullivaniii Pylaisiadelpha tenuirostris, Forsstroemia trichomitria (Figs.40, 42). For complete list see Iwatsuki (1992).

IV. B. 3. North-Pacific species.

Examples: Bartramiopsis lescurii, Oligotrichum parallelum, $O$. aligerum, Rhizomnium nudum, Pleuroziopsis ruthenica, Leptopterigynandrum austro-alpinum, Scouleria aquatica, Claopodium crispifolium, C. pellucinerve, Gollania turgens (Figs. 43-45). For more examples see Iwatsuki (1972).

IV. B. 4. More widespread species, $\alpha$ curing in Holarctic generally on E a $\mathbf{s}$ of both Eurasia and North America.

Examples: Bryhnia novae-angliae, Grimmia pilifera, Hookeria acutiloba, Taxiphyllum alternans, $T$. taxirameum. Herpetineuron toccoae (Figs. 42, 43).

V. ENDEMIC SPECIES. Al present there are known only two andemic genera from the territory of the former USSR: Mamillariella, with a single species, distributed in several localities of the South Far East, and Ortholontopsis, also monotypic, strictly confined to the upper taiga zone in Altai and Sayan Mts., South Siberia. The most of endemic species, at present, need to be additionally revised, since very few recent studies were undertaken on them. As the "good" species I can mention now Myuroclada rotundifolia, Forrstroemia stricta, Cinclidium minutifolium, and a few others. It 
is worthy to note, that these species belong to small, recently revised genera and are known so far from a few localities in forest zone of Asian part of the former USSR.

About $10 \%$ of species are difficult to link to either one of the above groups. They can be attributed to various smaller groups, but here I'm leaving them unclassified.

Overlapping the above types of distribution one can see the general pattern of diversity shown on Fig. 2 (p. 15). Some less diverse area in respect to mosses, however, can not be detected by using such a rather general method only.
A more detailed and more formal model of the bryodiversity of the territory of the former USSR would needs additional explorations of the mosses, especially in its Asiatic part. Also it hardly can be successful without a correlation of all the taxa throughout the whole Holarctic, and also without considering all of its territory.

\section{ACKNOWLEDGEMENTS}

I would like to thank Benito C. Tan for the valuable comments and the improvement of English language of preliminary version of the manuscript.

\section{LITERATURE CITED}

ABOLINA, A. А. [АБОЛИНb, А. А.] 1968. Mosses of Latvijan SSR. - [Листостебельные мхи Латвийской CCP]. Riga, Zinatne [Puza, Зинатне 1, 332.

ABRAMOV, I. I. \& A. L. ABRAMOVA [AEPAMOB, И. И., А. Л. АБРАMOВА] 1983. Conspect of bryoflora of Mongolian Popular Republic. [Конспект флоры мхов Монгольской Народной Республихи]. BioL Resursy i Prirodnye Usloviya Mongolskoj Narodnoj Respubliki /Euon. Pecypca u Природнье Условия монгольской Народной Pecnублики], 17: 1- 222.

AFONINA, O. M. [AФOHИHA, O. M.] 1989. A list of masses of Chukotka Peninsula. - [Список листостебельных мхов Чукотского полуострова]. In: Abramov, 1. I. (ed.) Problemy briologii v SSSR. Leningrad, Nauka (B кн.: Проблемы бриологии ө СССР (ред. И. Н. Абрамов) Л., Наука]: 5-29.

AGNEW, S. \& M. VONDRACEK 1975. A moss flora of Iraq. - Feddes Repert. 86(6-8): 341- 489.

ANDERSSON, L. E., H. A. CRUM \& W. R. BUCK 1990. List of the mosses of North America north of Mexico. - Bryologist 93(4): 448-499.

ARDEEVA, V. Ya. [APДEEBA, В. Я.] 1969. Mosses of Southern Saлhalinю - [Листостебельные мхи Южного Сахалина]. Ph. D. Thesis, Vladivostok. [Автореф...канд. биол наук, Владивосток], 30.

ATLAS SSSR (TOCHENOV, V. V., ed.) (ATJAC СССР (ред. ТОЧЕНОВ, В. В.] 1984. Moscow, Glavn. Upr. Geod. Kartogr. (M., ГУГK], 260.

BARDUNOV, L. V. [БАРДУНОВ, Л. B.] 1974. Mosses of the Altai and Sayan Mts. - [Листостебельные мхи Aлтая и Саян]. Nowosibirsk, Nauka [Новосибирск, Наука], 168.

BARDUNOV, L. $V$. \& V. Ya. CHERDANTSEVA [БАРДУНОВ, Л. В., В. Я. ЧЕРДАНЦЕВА] 1982. - Mosses of the South of Primorskij Province. [Листостебельные мхи Южного Приморья]. Nowsibirsk, Nauka [Новосибирск, Наука], 208.
BOROS, A. 1968. Bryogeographie und Bryoflora Ungarns. - Akademiai Kiado, Budapest. 468.

CAO, T. \& D. H. VITT 1986. A taxonomic revision and phylogenetic analysis of Grimmia and Schistidium (Bryopsida; Grimmiaceae) in China. - J. Hattori Bot. Lab. 61: 123-247.

CASAS, S. C. 1981. The mosses of Spain: an annotated check-list. - Treb. Inst. Bot. Barcelona 7: 1-57.

CHIKOVANI, N. V. [ЧИКОВAHИ, H. B.] 1986. Bryophyta. - In: Nachuzrishvili, I. G. (ed.) Flora sporovykh rastenij Gruzii. Tbilisi, Mizniereba ГФлора споровых растений Грузии (ред. Нахуцришвилиб И. Г.) Тбилиси, Мицниереба]: $786-851$.

CORLEY, M. F. V. \& A. C. CRUNDWELL 1991. Additions and amendments to the mosses of Europe. J.Bryol. 16(3): 337 - 356.

CROSBY, M. 1980. The diversity and relationships of mosses. - In: Taylor, R. J. \& A. E. Leviton (eds.) The mosses of North America. San Francisco, Californ. Acad. Sci.: 115 - 129.

CRUM, H. \& L. E. ANDERSON 1981. Mosses of the Eastern North America, I-II.- New York, Columbia Univ. Press, 1328.

CZEREPANOV, S. K. [YEPEMAHOB, C. K.] 1981. Vascular plants of the USSR. - [Сосудистые растения ССCP]. Leningrad, Nauka [Л., Hаука], 510.

DIRSKE, G. M., H. M. H. van MELIK \& A. TOUW 1988(1989). Checklist of Dutch bryophytes. - Lindbergia 14(3): 167-175.

DUELL, R. 1984. Distribution of the European and Macaronesian mosses (Bryophytina), 1. Bryol. Beitr. 4: $1-109$.

DUELL, R. 1985. Distribution of the European and Macaronesian mosses (Bryophytina), 2. Bryol. Beitr. 5: 110-232. 
DUELL, R., E. FISCHER \& L. HERMANN 1983. Verschollene und gefaehrdete Moospflanzen in Rheinland-Pfalz. - Beitr. Landespflege Rheinland-Pfalz : $107-132$.

EGGERS, J. 1982. Artenliste der Moose Macaronesiens. Cryptogamie. Bryol, Lichenol 3: 283-335.

EL-OQLAH, A. A., W. FREY \& H. KUERSCHNER 1988. The bryophyte flora of Trans-Jordan. A catalogue of species and floristic elements. - Willdenowia $18(1): 253$ - 279

FREY, W. 1986. Bryophyte flora and vegetation of South-West Asia. - Proc. Royal Soc. Edinburg 89B: 217-227.

GAO, Ch. \& K. C. CHANG 1983. Index muscorum Chinae boreali-orientalis. - J. Hattori Bot. Lab. 54: 187 $-205$.

HALLINGBAECK, T. \& L. SOEDERSTROEM 1987. Sveriges mossor ach deras svenska namn - en kommenterad checklista. - Svensk Bot. Tidskr. 81(6): 357-388.

HERRNSTADT, I., C. C. HEYN \& M. R. CROSBY 1991 A checklist of the mosses of Israel. - Bryologist 94(2): $168-178$

HILL, M. 1988. A bryophyte flora of North Wales. - $J$. Bryol. 15(2): 377 - 491 .

HULTEN, E. 1971. Altas oever vaexternas utbreding $i$ norden. Stockholm, Generalstabens Litografiska Anstalts Foerlag, 532.

IGNATOV, M. S. 1992. Relationships of moss flora of the Altai Mts. - Bryobrothera 1: 63-72.

IGNATOV, M. S. \& O. M. AFONINA (eds.) 1992. Check-list of mosses of the former USSR. - Arctoa 1: $1-85$.

IGNATOV, M. S. \& E. A. IGNATOVA [ИГНATOB, M. C., E. A. ИГHATOBA] 1988. Bryoflora of Kunzevo: changes within last centure and a half). [Бриофлора Куниева: изменения 3а полтора века]. - Bull. Glawn. Bot. Sada Acad. Sci. USSR [Бюля. Главн. Бот. Сада АН СССР] 147: 31-36.

IGNATOV, M. S. \& E. A. IGNATOVA [ИГНATOB, M. C., E. A. ИГHATOBA] 1990. Contributions to the bryoflora of Moscow Province. - [Материалы к познанию бриофлоры Московской области]. In: Skwortsov, A. K (ed.) Floristicheskie issledowania v Moskovskoj oblasti. Moscow, Nauka /Фropucтические исследования в Московской области (ред. Сквориов A.K.) M., Наука]: 121-179.

IGNATOVA, E. A. \& M. S. IGNATOV [ИГНATOBA, Е. А., М. С. ИГНАТОВ] 1992. Mosses of Bashkiria (South Ural Mts.): preliminary list of species and phytogeographical notes. - [Мхи Башкирии: предварительный список видов и фитогеографические заметки]. Bull Mosk. $O b$ shch. Isp. Prir. Otd. Biol. ГБюл. Mоск. O-ва Испытателей Прир. Отд. Биол/ 98(1): 103-111.

IRELAND, R. R. 1986. Synopsis of the genus Plagiothecium for North America. - Lindbergia 12(1): 49-56.

IRELAND, R. R., G. R. BRASSARD, W. B. SCHOFIELD \& D. H. VITT 1987. Checklist of mosses of Canada II. - Lindbergia 13(1-2): $1-62$.

IWATSUKI, Z. 1972. Distribution of bryophytes common to Japan and the United States. - In: Graham, $A$. (ed.) Floristics and paleofloristics of Asia and eastern North America. Amsterdam, Elsevier PubL Co.: 107-137.

IWATSUKI, Z. 1992. The moss flora of Japan and its North American connections. - Bryobrothera 1: 1-7.

JANSSENS, J. A. P., D. G. HORTON \& J. F. BASINGER 1979. Aulacomnium heterostichoides sp. nov., an Eocene mass from south central British Columbia. - Can. J. Bot. 57(20): 2150-2161.

JOHANNSSON, B. 1983. A list of Icelandian bryophyte species. - Acta Naturalist. Icelandica, 30: 1-29.

KANNUKENE, L. R. [KAHHYKEHE, Л. P.] 1986. Mosses of the Estonian SSR. - [Листостебелькые мхи Эстонской ССP]. Bot. Zhurn. [Бот. журн] 71 (2): 206-215.

KHMEIEV, K. Ph. \& N. N. POPOVA [XMENEB, $K$. Ф., H. H. [OIOBA] 1988. Bryophyte flora of Basin of Don River in Middle Course. - [Флора мохообразных бассейна Среднето Дона]. Voronezh, Izd. Voronezh. Univ. [Воронеж, uзд. Воронежского университета], 168.

KOMAROV, V. L. (ed.) [КОМАРОВ, В. Л.(ред.)] 1934-1960. Flora of the USSR, vols. I-XXX. [ФЛOPA CCCP, rT. I-XXX]. Moscow-Leningrad, Izd. Akad. Nauk SSSR [M.-J., Hӟ. AH CCCP].

KOPONEN, T., P. ISOVIITA \& T. LAMMES 1977. The bryophytes of Finiand: an annotated checklist. Flora Fennica 6: 1-77.

LAZARENKO, A. S. [ЛA3APEHKO, A. C.] 1944. Nemoral element in the bryoflora of the Soviet Far East. - [Неморалызый элемект бриофлоры Советскопо Дальнего Востока]. Sovetskaya Botanika [Советская ботаника] (1944) (6): 43-55.

LID, J. 1963. Norsk og Svensk Flora. - Oslo, Det Norske Samlaget. 800 .

LYUBARSKAYA, L. В. [ЛЮБAPCKAЯ, Л. Б.] 1986 Conspect of mosses of Azerbaidjan. - [КонсnekT флоры листостебельных мхов Азербайджана]. Baku, Inst. Bot. Akad. Nauk Azerb. SSR MSc. reseued VINITI No 34I-B86 [Бакy, Ннсm. Bom. AH АзСCР, pyкonuco den в ВИНИТИ $N^{\circ} 341$ $B 861,178$.

MALYSHEV, L. I. [MAJЫUEB, Л. К.] 1975. Quantitative analysis of flora: spatial diversity, ievel of species richness and representativeness of study area. - [Количественный анализ флоры: простран-ственное разнообразие, уровень вндово бо богатства и репрезентативность участков oбследования]. Bot. Zhurn. [Боп. Журн.] 60(11): $1537-1550$.

MAMATKULOV, U. К. [MAMATKУЛOB, У. К.] 1975. Mosses of the Darvaz Mt. Range. - [Лиственные мхи Дарвазскопо хребта]. Dushanbe, Donish (Дунанбе, Дониш), 100.

MAMATKULOV, U. K. [MAMATKУЛIOB, У. К.] 1989 Analysis of bryophyte flora of Pamiro-Alaj Mts. [Анализ бриофлоры Памнро-Алая]. Dushanbe, Donish [Душанбе, Доншщ], 320.

MANAKYAN, V. A. [MAHAKGH, B. A.] 1989a. A review of the bryollora of Armenia. - [О6зор 
бриофлоры Армения]. In: Abramov, I. I. (ed.) Problemy briologii v SSSR, Leningrad, Nauka IB кн: Проблемы бриологии в СССР (ред. Абрамов, Н. Н.), Л., Наука]: 157 - 165.

MANAKYAN, V. A. [MAHAKGH, B. A.] 1989b. Mosses of the South-Eastem Armenia. - [Листостебельные мхи Юто-Восточной Армении]. Erevan, Izd. Akad. Nauk Armen. SSR [Ереван, изд-єо AH AрмССP I, 314.

MELNICHUK, V. М. [МЕЛЬНИЧУК, В. М.] 1970. Handbook of mosses of central and southern European Part of USSR. - [Определитель лиственных мхов средней полосы и юга европейской части CССP]. Kiev, Naukova Dumka [Киев, Hаукова Думка], 444.

MULDIYAROV, Е. ҮA. [МУЛЬДИЯРОВ, Е. Я.] 1990. Handbook of mosses of Tomsk Province [Определитель листостебельньх мхов Томской области] Tomsk, Izd. Tomsk. Univ. [Томск, Изд. Томск. Ун-таI, 208.

MURRAY, B. M. 1987. Andreaeaceae. - In: Mogensen, G. (ed.) Illustrated moss flora of Arctic North America and Greenland. 3. Andreaeobryaceae Tetraphidaceae. Meddeleiser om Groenland, Bioscience 23: 6-24.

NOGUCHI, A. (1987) Illustrated moss flora of Japan. Pt.1. - Hattori Bot. Lab., Obi, Nichinan, 242.

OCHYRA, R., H. BEDNAREK-OCHYRA \& P. SZMAJDA 1990. Mosses (Musci). Pt.5. - In: Ochyra, R. \& P.Szmajda (eds.) Atlas of the geographical distribution of spore plants in Poland, Krakow - Poznan, W. Szafer Inst. Bot., Polish Acad. Sci. \& Adam Mickiewicz Univ., Series V, $52+10$ map.

OCHYRA, R. \& P. SZMAJDA. 1983. Mosses (Musci). Pt. 1. - In: Szweykowski, J. \& T. Wojterski (eds.) Atlas of the geographical distribution of spore plants in Poland. Series V. Warszawa - Poznan, Panstwowe Wydawnictwo Naukowe, $31+11$ maps.

OCHYRA, R., P. SZMAJDA \& H. BEDNAREKOCHYRA 1992a. List of mosses to be published in ATMOS. - In: Ochyra, R. \& P. Szmajda (eds.) Atlas of the geographical distribution of mosses in Poland, Krakow - Poznan, W. Szafer Inst. Bot., Polish Acad. Sci. \& Adam Mickiewicz Univ., 8: 914.

OCHYRA, R., P. SZMAJDA \& H. BEDNAREKOCHYRA 1992b. Hylocomiastrum umbratum (Hedw.) Fleisch. - In: Ochyra, R. \& P. Szmajda (eds.) Atlas of the geographical distribution of mosses in Poland, Krakow - Poznan, W. Szafer Inst. Bot., Polish Acad. Sci. \& Adam Mickiewicz Univ., Pt. 8: 67-7I + map.

OCHYRA, R., P. SZMAJDA, W. BOCHENSKI \& $K$. KARCZMARZ. 1988. Mosses (Musci). Pt. 4. - In. Tobolewski, Z. \& T. Wojterski (eds.) Atlas of the geographical distribution of spore plants in Poland. Series V. Warszawa - Poznan, Panstwowe Wydawnictwo Naukowe, $48+11$ maps.

PARTYKA, L. Ya. [ПАРTЫKA, JI. Я.] 1989. Bryoflora of Crimea Peninsula and its peculiarities. [Бриофлора Крыма и ее особенности]. In. Abramov, I. I. (ed.) Problemy briologii v SSSR, Leningrad, Nauka /B кн: Проблемы бриологии в
СССР (ред. Абрамов, И. И.), Л., Наука): 165 170.

PETROV, S. [ПETPOB, C.] 1975. Handbook of bryophytes of Bolgaria.- [Определител на мъховете в Болгария]. Sofia, Izd. Bolg. Akad. Nauk. [Софuх, Нзд. Бълz. Акад. Наук.], 536.

PRESTON, C. D. 1984. A check-list of Greek mosses. J. Bryol. $13(1)$ : 43-95.

REDFEARN, P. L. \& P.-C. WU 1986. Catalogue of the mosses of China.- Ann. Missouri Bot. Gard. 73(1): 177-208.

RYKOVSKIJ, G. Рh. [РЫКОВСКИЙ, Г. Ф.] 1980. Bryophytes of Berezinskij Biosphaerical Reserve. [Mохообразные Березинското биосферного заповедника]. Minsk, Nauka i tekhnika [Минск, Наука и Техника], 136.

SCHLJAKOV, R. N. \& N. A. KONSTANTINOVA [IIЛЯКОВ, P. Н., Н. А. КОНСТАНТИНОВА] 1982. Conspect of bryophyte flora of Murmansk Province. - [Конспект флоры мохообразных Мурманской области]. Apatity, Polar-Alpine Bot. Gard. [Anатиты, Полярно-Альпийский Бот. $\mathrm{Cad}$ ], 228.

SCHOFIELD, W. B. 1965 . Correlation between the moss floras of Japan and British Columbia, Canada. - J. Hattori Bot. Lab. 28: 17-42.

SCHOFIELD, W. B. 1972. Bryology in Arctic and Boreal North America and Greenland. - Can J. Bot. 50(5): IIII - 1133 .

SCHOFILED, W. B. 1980. Phytogeography of the mosses of North America (North of Mexico). - In: Taylor. R. J. \& A. E. Leviton (eds.). The mosses of North America, Californ. Acad. Sci., San Francisco: 131170.

SCHOFIELD, W. B. 1988a. Bryophyte disjunctions in the Northern Hemispere: Europe and North America. - Bot. J. Linn. Soc. 98(3): 21/-224.

SCHOFIELD, W. B. 1988b. Bryogeography and the bryophytic characterization of biogeoclimatic zones of British Columbia, Canada. - Can. J. Bot. 66(12): 2673-2686.

SCHOFIELD, W. B. \& H. A. CRUM 1972. Disjunctions in bryophytes. - Ann. Missouri Bot. Gard. 59: 174 202.

SIMONOV, G. P. [СИMOHOB, Г. П.] 1978. Handbook of mosses of Moldavian SSR. - [Определитель листостебельных мхов Молдавской СCP] Kishinev, Schtiinza [Кишинев, Штиинца], 168.

SMITH, A. J. E. 1978. The moss flora of Britain and Ireland. - Cambridge, Cambridge Univ. Press, 706.

SPENCE, J. R. 1988. Checklist of the mosses of the Intermountain West, USA. - Great Basin Natur. 48(3): 394-401.

STEPANOVA, N. A. [CTEILAHOBA, H. A.] 1986. Conspect of moss flora of Yakutian tundras. [Конспект флоры мхов тундр Якутии]. Yakutsk, Yakutsk. fil. Sibir. Otd. Akad. Nauk USSR. [Якутск, Якутский филиал СО АН СССР], 120.

STOERMER, P. 1969. Mosses with a wetsern and southern distribution in Norway. - Universitetsforlaget. Oslo - Bergen - Tromso, 288. 
SZMAJDA, P. H. BEDNAREK-OCHYRA \& $R$. OCHYRA. 1991. Mosses (Musci). Pt.7. - In: Ochyra, R. \& P. Szmajda (eds.) Atlas of the geographical distribution of spore plants in Poland, $W$. Szafer Inst. Bot., Polish Acad. Sci. \& Adam Mickiewicz Univ., Krakow - Poznan. Series V, $52+10$ map.

TOUW, A. \& W. V. RUBERS 1989. De Nederlandse Bladmossen. - Utrecht, Stichting Uitgeverij wan de Koninklijke Nederlandse Natuurhistorische Vereniging, 532.

TOUW, A. 1974. Some notes on taxonomic and floristic research on exotic mosses. - J. Hattori Bot. Lab. 38: $123-128$.

TUTIN, T. G. (ed.) 1964-1980. Flora Europaea, vols. 1V. - Cambridge, Cambridge Univ. Press.

VIRCHENKO, V. М. [ВИРЧЕНКО, В. М.] 1989. Bryophytes of forest-steppe part of Pridneprovskaya Upland (conspect of flora). - [Mохообразные лесостепной части Прнднепровской возвышенности (конспект флоры)]. Kiev, Ukrainian Bot. Journ. Msc. reserwed VINITI, $N^{\circ}$ 84-B89 /Киев, Укр. боm. журн., Деп в ВННИТИ $\left.N^{\circ} 84-B 89\right], 61$.

VYUNOVA, G. V. [BbЮHOBA, Г. B.] 1980. Contribution to bryoflora of Leningrad Province. [Материалы к изучению бриофлоры Ленинградской области]. Novosti Sist. Nizsh. Rast. [Hов. сист. низи. раст.] 17: 216-230.

VOROBJEV, Yu. M. [BOРОБbEB, Ю. М.] 1983. Bryophytes of Gorkij Province (conspect of flora). [Мохообразные Горьковской области (конспект флоры)]. Gorkij, Gork. Univ., Msc. reserved VINITI, No 6871-B83 [Горький, Горьх. Ун-m, den. в ВИНИТН, $N^{\circ} 6871-B 83 /, 130$.
WOROSCHLLV, V. N., A. K. SKVORTSOV \& V. N. TIKHOMIROV [BOPOШИЛOB, B. H., A. K. СКВОРЦОВ, В. Н. ТИХОМИРОВ] 1966. Handbook of plants of Moscow Province - [Определитель растений Московской области]. Mascow, Nauka [M., Hayka], 367.

WU, P.-C. 1992. The East Asiatic genera and endemic genera of the bryophytes in China. - Bryobrothera 1: $99-117$.

YUKONENE, I. P. [ЮKOHEHE, И. П.] 1991. Present state of the exploration of bryoflora of Lietuva. [Состояние изученности бриофлоры Литвы]. In. Demkiv, O. T. (ed.) Briologia y SSSR, ee dostizhenia $i$ perspectivy, Lvov, Akad. Nauk SSSR, Akad. Nauk. USSR IB кн: Бриология - СССР, еe достихения и перспективь (ред. О. Т. Демкив), ЛbeOs, АН СССР, АH УCCP]: 201-204.

YURTSEV, B. A., A. I. TOLMACHEV \& O. V. REBRISTAYA [КРЦЕВ, Б. А., А. И. ТОЛМАЧЕВ, O. В. РЕБРИСТАЯ] 1978. Floristic delimitation and division of Arctic. - [Флористическое ограничение и разделение Арктики]. In: Yurtsev, B.A.(ed.) Arcticheskaya floristicheskaya oblast. Leningrad, Nauka IB кн: Apкmuческая флористическая область (ред. Юрчев, Б. А.), Л., Наука]: 9-67.

ZHELEZNOVA, G. V. [ЖЕЛE3HOBA, Г. В.] 1991. Geographical analysis of species composition of mosses of Komi SSR. - [Географический анализ видового состава листостебельных мхов Коми CCP]. In: Demkiv, O. T. (ed.) Briologia v SSSR, ee dostizhenia $i$ perspectivy, Lwov, Akad. Nauk SSSR, Akad. Nauk. USSR IB кн.: Бриология 6 СССР, ее достихения и перспехтивы (ред. O. $T$. Демкия), ЛЬв08, АН СССР, АН УССР]: 87-90. 